\title{
Patrones de circulación superficial sobre la plataforma interna entre bahía EI Uno y Punta de Las Vacas, Golfo de Urabá, Caribe colombiano
}

\author{
Surface circulation patterns above the coastal shelf between El Uno \\ bay and Las Vacas spit, Gulf of Urabá, Colombian Caribbean
}

\author{
Dannys Paola Hernández Morales ${ }^{1}$, Yorlenys Romaña Torres ${ }^{I}$, Alfredo Jaramillo-Vélez²*, \\ $\begin{array}{lll}\text { (iD) } 0000-0003-3591-4876 & \text { (ID) } 0000-0002-8580-2875 & \text { (iD) } 0000-0002-4901-0416\end{array}$ \\ Josep L. Pelegri $i^{3}$ y Vladimir G. Toro ${ }^{4}$ \\ (iD) $0000-0003-0661-2190$ (iD $0000-0003-4398-9472$
}

1. Universidad de Antioquia, sede Ciencias del Mar.Turbo-Antioquia,Colombia.dannyshernandez27@gmail.com,yorlenysromana@gmail.com

2. Grupo de Investigaciones Marinas y Costeras GISMAC. Universidad de Antioquia, Facultad de Ingeniería, sede Ciencias del Mar. Turbo-Antioquia, Colombia.alfredo.jaramillov@udea.edu.co*

3. Institut de Ciències del Mar, CSIC. Passeig Marítim de la Barceloneta, Barcelona, España.pelegri@icm.csic.es

4. Grupo de Investigación en Ingeniería y Gestión Ambiental - GIGA. Universidad de Antioquia, Facultad de Ingeniería, sede Ciencias del Mar. TurboAntioquia,Colombia.vladimir.toro@udea.edu.co

* Autor por correspondencia.

\section{RESUMEN}

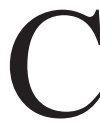

onocer los patrones de circulación costera es fundamental para gestionar adecuadamente la franja litoral, especialmente en áreas con alta presión antrópica. Con el objetivo de determinar las características de las corrientes costeras en el golfo de Urabá, se midieron y analizaron los patrones estacionales de circulación superficial durante las épocas de mucha y poca lluvia a lo largo de $6 \mathrm{~km}$ de costa, entre las espigas litorales de punta de Las Vacas y punta Yarumal del municipio de Turbo, Antioquia. Estas mediciones se realizaron con derivadores superficiales, que fueron lanzados en diversos estadios de la marea y rastreados durante periodos cercanos al ciclo semidiurno. Las mediciones in situ se analizaron considerando la evolución de la marea y los vientos observados en una estación climática ubicada cerca del golfo. Los patrones de circulación mostraron un comportamiento diferente durante las dos estaciones del año. La temporada de mucha lluvia, con vientos del sur, presentó trayectorias hacia el norte y la temporada de poca lluvia, con vientos del norte, las trayectorias fueron hacia el sur. Aunque los patrones de circulación mostraron una fuerte relación con la marea y el viento, las trayectorias de algunos derivadores se modificaron localmente por la presencia de geoformas como las bahías de Turbo y El Uno.

PALABRAS CLAVES: circulación superficial, viento, marea, derivadores, corrientes costeras.

\section{ABSTRACT}

$\mathrm{G}$ ood knowledge of the coastal circulation patterns is essential for a proper management of the coastline, especially in areas with a high anthropic pressure. In order to determine the main characteristics of the coastal currents in the Gulf of Urabá, the seasonal patterns of surface circulation were measured and analyzed during times of high and low rainfall along $6 \mathrm{~km}$ of coastline, between the Punta de Las Vacas and Punta Yarumal coastal spit systems, in the municipality of Turbo, Antioquia. These measurements were made with surface drifters, which were launched at different tide stages and tracked for time periods based on the semi-diurnal cycle. The in-situ measurements were analyzed alongside tide and wind data from a climatic station located near the gulf. The circulation patterns behaved differently depending on the season of the year. In the rainy season, with southerly winds, the drifters moved mainly towards the north while during the dry season, with northerly winds, all the drifters moved to the south. Although the circulation patterns showed a strong relationship with the tidal cycle and wind conditions, the Turbo and El Uno Bays modified some of the drifter's paths.

KEYWORDS: surface circulation, wind, tide, drifters, coastal currents.

DOI: https://doi.org/10.25268/bimc.invemar.2021.50.2.993 Publicado por INVEMAR

Este es un manuscrito de acceso abierto bajo la licencia CC 


\section{INTRODUCCIÓN}

El mar Caribe, y en particular su sector suroccidente, se caracteriza por un complejo sistema de corrientes (Ricaurte-Villota y Bastidas, 2017). Los procesos físicos que controlan estas corrientes varían notablemente desde las regiones profundas, fuera del talud continental, hasta la propia franja litoral (Grifoll et al., 2016). El resultado es que las características de las corrientes varían notablemente dependiendo de su localización, exhibiendo una gran variabilidad espaciotemporal. Durante las últimas décadas, algunos estudios han contribuido a mejorar nuestra comprensión de los principales procesos oceanográficos del Caribe, desde la dinámica del sistema de surgencia en la Guajira (Correa-Ramírez et al., 2020) hasta los patrones de circulación y distribución de masas de agua en el Caribe suroccidental (Lozano-Duque et al., 2010; Escobar, 2011; Toro, et al., 2019). A pesar de estos estudios sobre el suroeste del Caribe colombiano el conocimiento de su hidrodinámica todavía es insuficiente. Esto es particularmente evidente en lugares como el golfo de Urabá, donde existe una carencia de mediciones sistemáticas de parámetros oceanográficos. Esto se ha evidenciado en el diseño de proyectos costeros que se han realizado con información secundaria o a partir de alguna campaña puntual. El incremento de inversiones a corto y mediano plazo en la región reafirma la importancia y pertinencia de mediciones oceanográficas in situ. Un caso específico es el municipio de Turbo, ubicado en el margen sureste del golfo de Urabá, donde en los últimos años se han incrementado las propuestas de proyectos para la prestación de servicios turísticos, portuarios y comerciales sobre su línea de costa.

La mayoría de las propuestas y proyectos consideran mediciones de parámetros climáticos, pero escasamente incluyen datos oceanográficos. De esta manera, no se han tenido en cuenta los efectos que el régimen de corrientes puede tener sobre la dinámica de sedimentos y la geomorfología del lugar. Un caso particular fueron las modificaciones que en 2015 evidenció la playa urbana de Turbo, debido al cierre de la única bocana de la bahía El Uno ubicada originalmente al sur de esta y contigua a la playa urbana del municipio (Alcántara et al., 2019). Esta bahía le fue abierta una bocana cerca del delta del rio Turbo (al norte de la bahía), la cual ha venido aumentando su ancho en los últimos años. Según Alcántara et al. (2019), este cierre/apertura de bocanas generó un desequilibrio en la dinámica de sedimentos en toda el área. El cierre de la bocana sur produjo una acreción significativa de arenas en la playa municipal dando origen a la denominada playa Dulce (antes

\section{INTRODUCTION}

The Caribbean Sea, especially its southwestern sector, is characterized by a complex system of currents (Ricaurte-Villota and Bastidas, 2017). There is a wide variation of physical processes that control these currents depending on whether they occur in deep waters, beyond the continental slope, or near to the coastline (Grifoll et al., 2016). This leads to significant differences in the characteristics of the currents depending on their location, with large spatiotemporal variability. In recent decades, a number of studies have contributed to improving our understanding of the main oceanographic processes in the Caribbean, from the dynamics of the upwelling system in the Guajira (Correa-Ramírez et al., 2020) to the circulation patterns and distribution of water masses in the southwestern Caribbean (Lozano-Duque et al., 2010; Escobar, 2011; Toro, et al., 2019). Nevertheless, despite these studies concerning the southwestern Colombian Caribbean, knowledge of its hydrodynamics is still insufficient. This is particularly evident in places such as the Gulf of Urabá, where there is a lack of systematic measurements of oceanographic parameters. This has been evidenced in the design of coastal projects based on secondary information or on the basis of a single survey. The increase in short- and mediumterm investments in the region underscores the importance and relevance of in situ oceanographic measurements. An example is the municipality of Turbo, located on the southeastern side of the Gulf of Urabá, where in recent years there has been an increase in project proposals for the development of tourism, port, and commercial services along the coastline.

Most of these proposals and projects take into account measurements of climatic parameters, but they rarely include oceanographic data. Consequently, the effects that the system of currents may have on the sediment dynamics and geomorphology of the site have not been considered. A particular case was evidenced by changes in Turbo's municipal beach in 2015, as the movement of sediment closed off the mouth of the bay of El Uno, which neighbors the beach to the north (Alcántara et al., 2019). A new artificial inlet was opened near the delta of the Turbo River (to the north of the bay), and this inlet has been widening in the last few years. According to Alcántara et al. (2019), the closing and opening of inlets to the bay has caused an imbalance in the sediment dynamics of the entire area. The closure of the southern inlet produced a significant increase in sand on the municipal beach, creating 
llamada playa Barajas) y demás sectores al sur. En contraste, la apertura de la bocana norte provocó una modificación en la circulación alrededor del delta y condujo a la erosión de la flecha litoral (punta Yarumal) que conecta al norte de playa Dulce. El desequilibrio provocado evidencia la necesidad de conocer las dinámicas locales actuales y así predecir de una manera adecuada el comportamiento de la costa frente a cualquier acción (natural/antrópica) sobre la línea de costa.

A nivel del golfo de Urabá, se han realizado estudios utilizando modelación numérica para explicar el comportamiento de las corrientes. Montoya y Toro (2006), utilizando el modelo hidrodinámico ELCOM, determinaron que las corrientes superficiales están condicionadas principalmente por la descarga del río Atrato. Toro et al. (2019), usando el modelo ROMS, encontraron que el golfo se puede analizar en tres regiones (norte, centro y sur) donde, dependiendo de la época del año, la circulación es modulada por el campo de vientos y/o la descarga del río. En general, estos experimentos numéricos se han realizado a escalas espaciales de orden de kilómetros. Si bien han sido aportes importantes a la comprensión de la hidrodinámica en el golfo, el estudio de la franja litoral requiere reducir aún más la escala espacial.

Con el fin de obtener información de las corrientes superficiales, en especial las costeras, es común usar derivadores superficiales. En sitios cercanos a la línea de costa se utilizan derivadores durante escalas de tiempo que varían entre minutos y días, dependiendo del fenómeno a estudiar (Shafiei y Abbas, 2011). Además, los derivadores son una alternativa de bajo costo si se tiene en cuenta que algunos de ellos utilizan tecnología GPS convencional, que ha demostrado un grado adecuado de precisión (MacMahan et al., 2009). Adicionalmente, si se pretende estudiar la contribución de la marea, es necesario registrar las corrientes durante un ciclo completo del período de la marea.

El presente trabajo pretende avanzar en el entendimiento de los patrones de las corrientes superficiales en un sistema local dentro del golfo de Urabá, como son las playas urbanas del municipio de Turbo. Con este fin se realizaron cuatro campañas, dos en época de mucha lluvia y dos en poca lluvia, en las cuales se midieron las corrientes superficiales usando derivadores entre Punta de Las Vacas y la bocana de bahía El Uno. Estas mediciones permitieron determinar la dirección y velocidad de las corrientes durante periodos de aproximadamente $10 \mathrm{~h}$, las cuales se contrastaron con el nivel de la marea y con mediciones de la dirección y magnitud del viento. the area known as Playa Dulce (formerly known as Playa Barajas) and other areas to the south of it. In contrast, the opening of the northern inlet modified sediment circulation around the delta and caused the erosion of the coastal spit (Punta Yarumal) that connects to the northern end of Playa Dulce. This imbalance demonstrates the need to understand the ongoing local dynamics in order to adequately predict the behavior of the coastline in the event of any natural or anthropogenic activity along the shore.

Studies have been conducted in the Gulf of Urabá using numerical modeling to explain the behavior of currents. Montoya and Toro (2006), using the ELCOM hydrodynamic model, determined that surface currents are mainly shaped by the outflow of the Atrato River. Toro et al. (2019), using the ROMS model, found that the Gulf can be divided into three regions (north, center and south) depending on the time of the year, where the circulation is modulated by the wind field and/or the river outflow. In general, these numerical experiments have been carried out at spatial scales of the order of kilometers. Although they have made important contributions to the understanding of the hydrodynamics in the Gulf, the study of the coastal strip requires research on a smaller spatial scale.

Surface drifters are commonly used to obtain information on surface currents, especially coastal currents. At sites close to the coastline, drifters are used over time scales ranging from minutes to days, depending on the phenomenon to be studied (Shafiei and Abbas, 2011). Moreover, drifters are a low-cost alternative when considering that some of them use conventional GPS technology, which has been demonstrated to have an adequate degree of accuracy (MacMahan et al., 2009). If the influence of the tides is also to be studied, it will be necessary to record the currents during a full tidal cycle.

The aim of this study is to advance understanding of the patterns of surface currents of a local system within the Gulf of Urabá, such as those along the urban beaches of the municipality of Turbo. To achieve this, four rounds of measurements were carried out, two in periods of high rainfall and two in periods of low rainfall, sampling the surface currents through drifters deployed between Las Vacas spit and the inlet of El Uno bay. These measurements made it possible to determine the direction and speed of the currents over periods of approximately $10 \mathrm{~h}$, which were then compared with the tide level and with measurements of wind direction and speed. 


\section{ÁREA DE ESTUDIO}

El golfo de Urabá es el estuario más grande del mar Caribe colombiano, ubicado en su extremo suroccidental, entre las coordenadas $7^{\circ} 55^{\prime}$ y $8^{\circ} 40^{\prime} \mathrm{N}$ y $76^{\circ} 53^{\prime}$ y $77^{\circ} 23^{\prime} \mathrm{O}$. El golfo está abierto al mar Caribe por su extremo norte, con una longitud norte-sur aproximada de $80 \mathrm{~km}$ y un ancho que varía entre 15 y $50 \mathrm{~km}$. Su litoral costero, entre cabo Tiburón (Chocó) y punta Rey (Antioquia), presenta una longitud de $512 \mathrm{~km}$ (Prüssmann y Correa, 2012). Destaca el importante aporte fluvial promedio del río Atrato, con un caudal promedio mensual cercano a $3000 \mathrm{~m}^{3} / \mathrm{s}$ y variaciones que oscilan entre 1000 y $5000 \mathrm{~m}^{3} / \mathrm{s}$. Se trata de un golfo relativamente somero, con valores de profundidad que no superan $30 \mathrm{~m}$ en bahía Colombia (sur) y en el delta del río Atrato, mientras que sus mayores profundidades se encuentran al norte en su conexión con el mar Caribe (60 m aproximadamente) (Brakenridge et al., 2021).

\section{STUDY AREA}

The Gulf of Urabá is the largest estuary in the Colombian Caribbean Sea, located in its southwestern corner, between coordinates $7^{\circ} 55^{\prime}$ and $8^{\circ} 40^{\prime} \mathrm{N}$ and $76^{\circ} 53^{\prime}$ and $77^{\circ} 23^{\prime} \mathrm{W}$. The Gulf is open to the Caribbean Sea at its northern end, with an approximate north-south length of $80 \mathrm{~km}$ and a width varying between 15 and $50 \mathrm{~km}$. Its coastline, between Cape Tiburón (Chocó) and Rey spit (Antioquia), is $512 \mathrm{~km}$ long (Prüssmann and Correa, 2012). It is important to highlight that the Atrato River has an average annual flow of about $3000 \mathrm{~m}^{3} / \mathrm{s}$ that can vary between 1000 and $5000 \mathrm{~m}^{3} / \mathrm{s}$. The Gulf of Urabá is relatively shallow, with depth values that do not exceed $30 \mathrm{~m}$ in Colombia bay (south) and in the Atrato delta, while its greatest depths are found to the north where it joins the Caribbean Sea (approximately $60 \mathrm{~m}$ ) (Brakenridge et al., 2021).

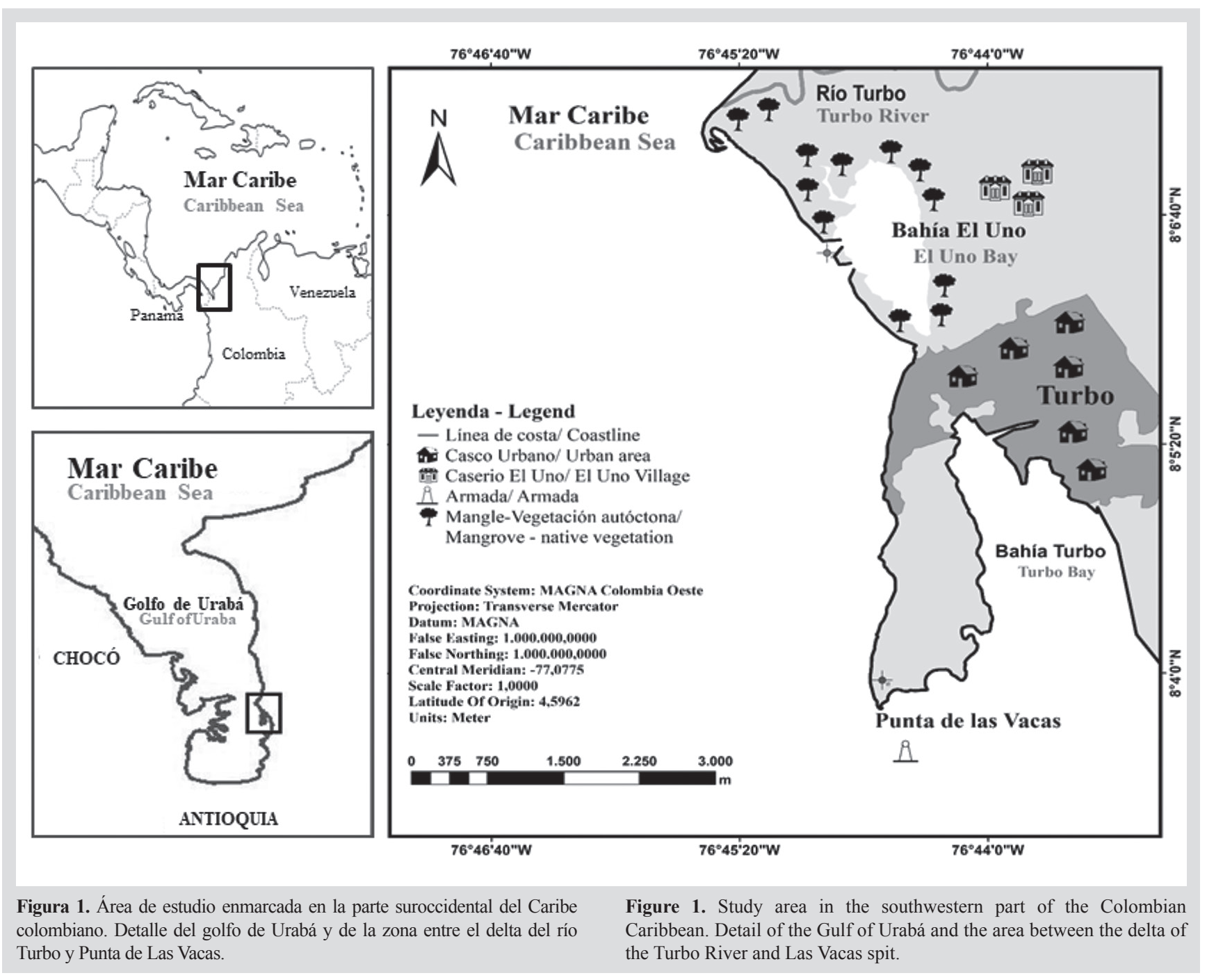


Respecto a su clima, el golfo de Urabá se encuentra bajo la influencia de la Zona de Convergencia Intertropical (ZCIT), la cual se desplaza hacia el sur, entre diciembre y abril, presentando la época de poca lluvia, cuando los promedios mensuales de precipitación se encuentran por debajo de $80 \mathrm{~mm} / \mathrm{mes}$, caracterizada por fuertes vientos alisios del nororiente; entre los mayo y noviembre, la ZCIT se desplaza al norte y se presenta la época de mucha lluvia, con valores por encima de $150 \mathrm{~mm} / \mathrm{mes}$, con vientos del sur y suroccidente de menor intensidad (Invemar, 2003). La dinámica del golfo está fundamentalmente influenciada por las descargas del rio Atrato, la dirección e intensidad del viento, la energía de las olas, las mareas y los gradientes de densidad (Lonin y Vásquez, 2005; Escobar, 2011, Escobar et al., 2019). Se han observado cambios en la dirección de la corriente con la profundidad, que sugieren la existencia de un patrón de circulación estuarino, con aguas superficiales que se dirigen hacia el norte del Golfo y aguas más profundas que se dirigen desde el mar Caribe hacia el sur del mismo.

La marea es semidiurna mixta, con una amplitud media de $0,28 \mathrm{~m}$ y con valores promedios de $0,09 \mathrm{~m}$ en cuadratura y de $0,50 \mathrm{~m}$ en sicigia (IDEAM, 2019). Estos valores sugieren una amplificación importante con respecto a la marea en la plataforma exterior, cuyo rango no excede $\pm 0,25 \mathrm{~m}$ (Kjerfve, 1981). Los componentes principales de mareas son dos armónicos semidiurnos (M2, 0,09 m; N2, 0,03 m) y dos diurnos (K1, 0,10 m; O1, 0,06 m) (Nienhuis, 2019). En cuanto al oleaje, el golfo de Urabá se puede caracterizar de acuerdo con su ubicación espacial y a la época climática, con alturas medias significativas alrededor de 0,75 y 1,5 m durante las épocas de poca y mucha lluvia, respectivamente (Escobar et al., 2015).

El municipio de Turbo está ubicado en el margen suroriental del golfo de Urabá, frente al delta del río Atrato (Figura 1). Entre punta Yarumal (desembocadura del río Turbo) y Punta de Las Vacas se destacan cuatro áreas según su uso de suelo: al norte y al sur dos áreas de cobertura vegetal (espigas litorales de punta Yarumal y de Punta de Las Vacas); un área de playa de arena (playa Dulce), que va desde la antigua bocana de bahía El Uno hasta el espolón ubicado en medio de la espiga litoral de Punta de Las Vacas; y un área residencial-comercial que va desde el espolón mencionado hasta las instalaciones de capitanía de puerto. Cabe destacar que bahía El Uno es una laguna costera contenida por una flecha litoral generada por la desembocadura del río Turbo. Hasta 2015, esta bahía tenía su bocana natural a un costado de playa Dulce, pero posteriormente fue cerrada y se abrió una bocana artificial más cerca de la desembocadura del rio Turbo (Alcántara et al., 2019).
The climate of the Gulf of Urabá is influenced by the Intertropical Convergence Zone (ITCZ), which moves southward between December and April, bringing with it a period of low rainfall, with monthly rainfall averages below $80 \mathrm{~mm} / \mathrm{month}$ and strong trade winds from the northeast. Between May and November, the ITCZ shifts to the north and the rainy season arrives, with more than $150 \mathrm{~mm} / \mathrm{month}$ of rainfall, with less intense winds from the south and southwest (Invemar, 2003). The Gulf's dynamic is primarily shaped by outflows from the Atrato River, wind direction and intensity, wave energy, tides and density gradients (Lonin and Vásquez, 2005; Escobar, 2011; Escobar et al., 2019). Changes in current direction have been observed at different depths, suggesting the existence of an estuarine circulation pattern, with surface waters moving northward towards the Caribbean Sea and deeper waters moving southward into the Gulf.

The tide is mixed semidiurnal, with mean amplitude of $0.28 \mathrm{~m}$ and average values of $0.09 \mathrm{~m}$ during neap tides and $0.50 \mathrm{~m}$ during spring tides (IDEAM, 2019). These values suggest a significant amplification with respect to the outer shelf tide, whose range does not exceed $\pm 0.25 \mathrm{~m}$ (Kjerfve, 1981). The principal tidal components are two semi-diurnal harmonics (M2, $0.09 \mathrm{~m}$; $\mathrm{N} 2,0.03 \mathrm{~m})$ and two diurnal harmonics $(\mathrm{K} 1,0.10 \mathrm{~m}$; O1, $0.06 \mathrm{~m}$ ) (Nienhuis, 2019). Swell can be characterized according to the Gulf's spatial position and climate season, with significant mean heights about 0.75 and $1.5 \mathrm{~m}$ during the low and high rain seasons, respectively (Escobar et al., 2015).

The municipality of Turbo is located on the southeastern shore of the Gulf of Urabá, facing the Atrato River delta (Figure 1). Between Yarumal spit (mouth of the Turbo River) and Las Vacas spit, the land can be divided into four areas according to their use: to the north and south there are two areas of vegetation cover (the coastal outcrops of Yarumal spit and Las Vacas spit); an area of sandy beach (Playa Dulce), which goes from the old inlet of El Uno bay to the spur located in the middle of the Las Vacas coastal spit; and a residential-commercial area that runs from the spur mentioned above to the port authority's facilities. It should be noted that El Uno bay is a coastal lagoon enclosed by a barrier spit formed by the mouth of the Turbo River. Until 2015, the natural inlet of this bay was located on one side of Playa Dulce, but it was closed and an artificial inlet opened closer to the mouth of the Turbo River (Alcántara et al., 2019). 


\section{MATERIALES Y MÉTODOS}

Para nuestro estudio se utilizaron dos derivadores superficiales de bajo costo, construidos con materiales como tubos de PVC y una draga de forma esférica con tres planos de exposición, manufacturada según diseño de Lucero y Mindiola (2007). Cada uno de los derivadores consta de dos componentes: la parte superior es un recipiente sellado, que contiene en su interior un GPS programado en modo "track", y la parte inferior es una draga, diseñada para moverse de acuerdo con la dirección principal de la corriente (Lucero y Mindiola, 2007). El diseño fue realizado de tal manera que el centro de masa estuviera ubicado bajo la superficie del agua, de tal manera que se estuvieran monitoreando las corrientes entre 0,5 y $1,5 \mathrm{~m}$ de profundidad (Figura 2).

\section{MATERIALS AND METHODS}

Two low-cost surface drifters were used for our study, constructed with materials such as PVC containers and a spherical drogue with three planes of exposure, manufactured according to the design of Lucero and Mindiola (2007). Each drifter is made of two components: the upper part is a sealed container, which contains a GPS set to "track" mode, and the lower part is the drogue, designed to be dragged by the current (Lucero and Mindiola, 2007). The drifter was designed in such a way that the center of mass was located below the water surface, so that the currents were monitored at a depth of 0.5 to $1.5 \mathrm{~m}$ (Figure 2).

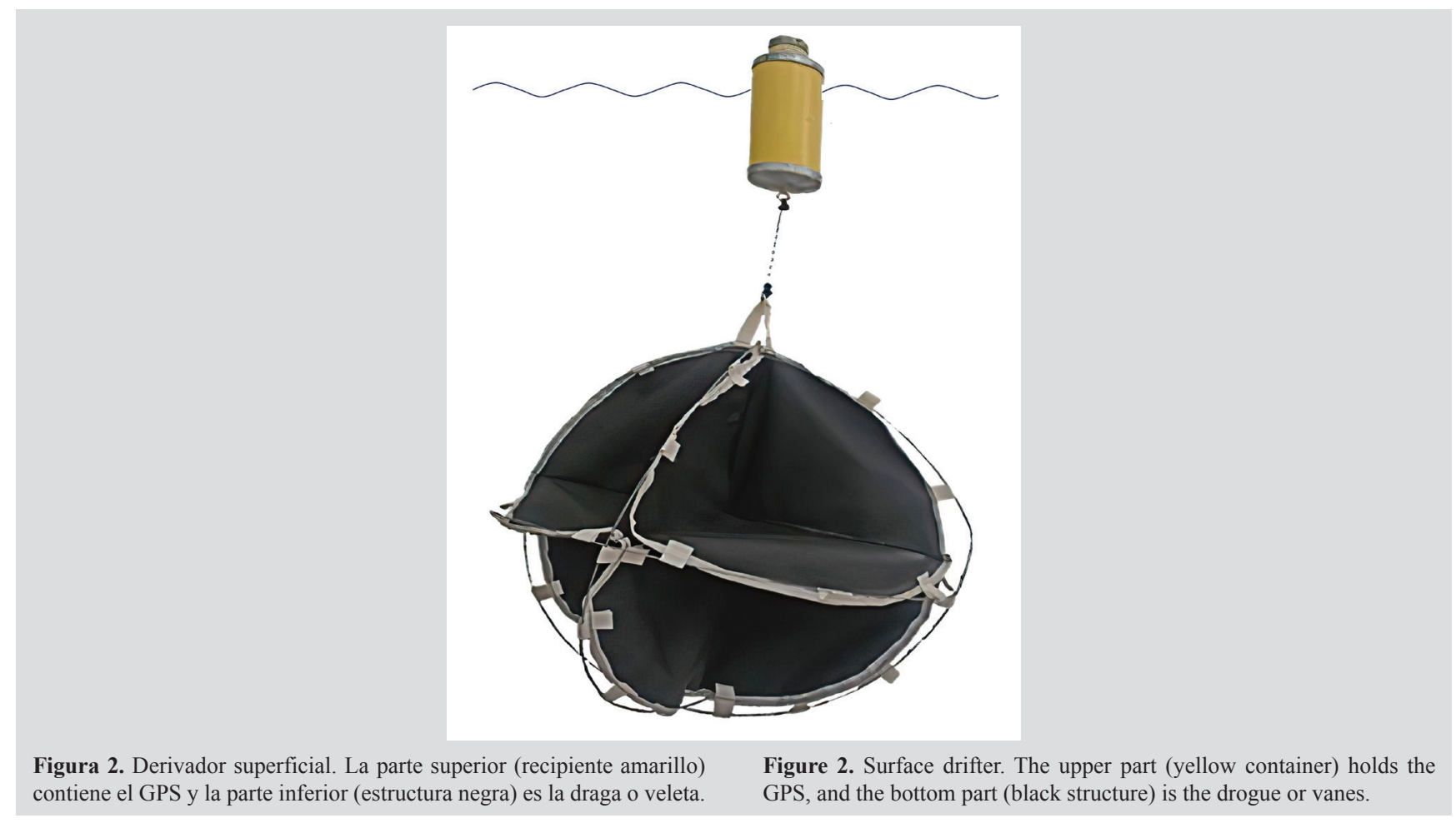

El área de estudio se dividió en dos: la 1, entre la espiga litoral de punta Yarumal y playa Dulce, y la 2 entre playa Dulce y Punta de Las Vacas (Figura 3). Se realizaron cuatro campañas de medición: dos en época de mucha lluvia (12 y 18 de noviembre, 2017) y dos en época de poca lluvia (24 y 31 de enero, 2018). En cada una de ellas se realizaron, en promedio, cuatro lanzamientos de derivadores, distribuidos en las áreas mencionadas, a una distancia de unos $500 \mathrm{~m}$ de la costa y en profundidades mayores a $2 \mathrm{~m}$. El tiempo de duración de cada campaña fue de aproximadamente $10 \mathrm{~h}$,
The study area was divided into two zones: zone 1, between the coastal outcrop at Yarumal spit and Playa Dulce, and zone 2, between Playa Dulce and Las Vacas spit (Figure $3)$. Four rounds of measurements were conducted: two in the rainy season (November 12 and 18, 2017) and two in the dry season (January 24 and 31, 2018). In each experiment, drifters were launched an average of four times, distributed in the aforementioned zones, at a distance of about $500 \mathrm{~m}$ from the coast and more than $2 \mathrm{~m}$ deep. The duration of each launch was approximately $10 \mathrm{~h}$, so that the drifters could 
de forma que los derivadores se pudieran seguir visualmente con luz del día y así alcanzar a cubrir la mayor parte del ciclo de marea. Los datos medidos cada minuto con ayuda del GPS fueron las ubicaciones (latitud y longitud) y tiempos correspondientes (fecha y hora). Con estos datos medidos entre dos puntos, se calculó la magnitud y dirección de la velocidad superficial, y a su vez las componentes zonal y meridional de la velocidad $(u, v)$. be followed visually in daylight and thus covered most of the tidal cycle. Every minute the GPS recorded the location (latitude and longitude) and corresponding time (date and time). Using these data recorded between two points, the surface velocity and direction were calculated, as well as the zonal and meridional components of the velocity $(u, v)$.

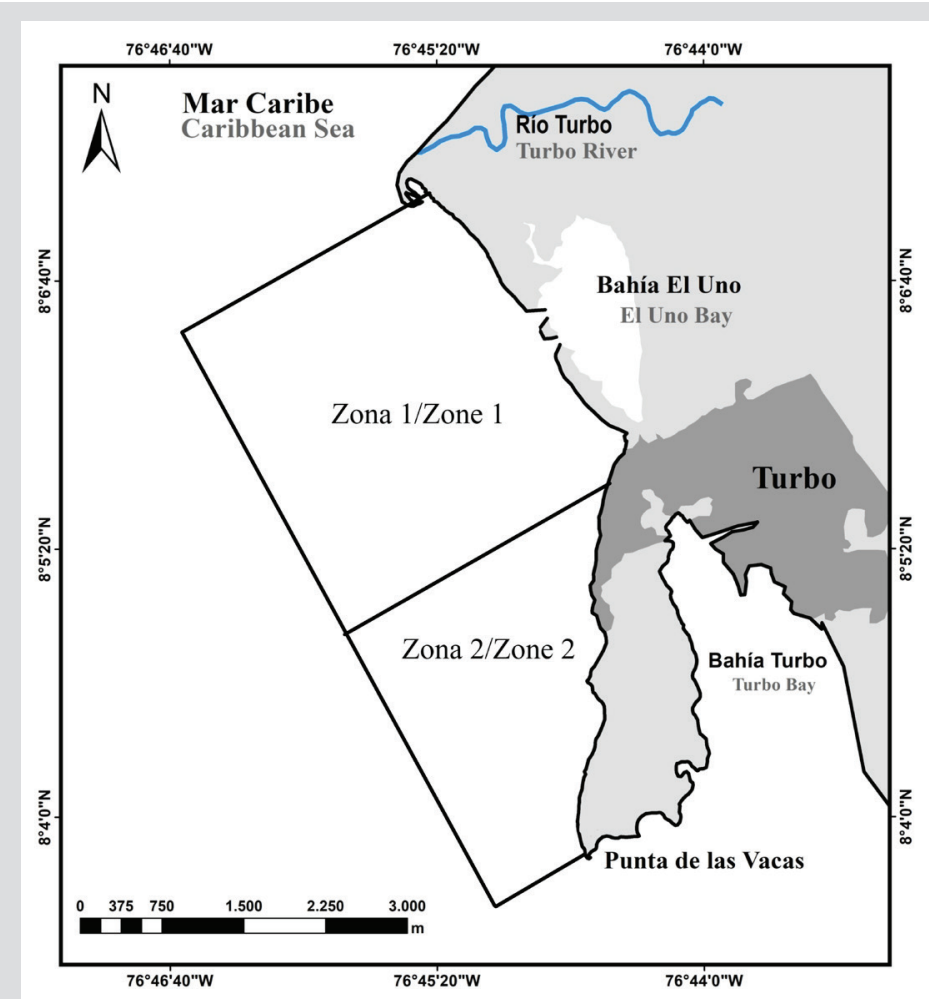

Figura 3. Áreas de estudio donde se realizaron las mediciones con los derivadores.

Figure 3. Study zone where the drifter measurements were carried out.

Con el fin de entender el comportamiento de las corrientes se analizaron datos de viento (magnitud y dirección) y de marea. Los datos de viento corresponden a promedios entre 1 y 6 h de una estación del Centro de Investigaciones Oceanográfica e Hidrográficas $(\mathrm{CIOH})$ localizada en la parte norte del golfo de Urabá (Sapzurro, Chocó). Teniendo en cuenta los resultados sobre la variabilidad espacial del campo de viento en el golfo de Urabá (Toro et al., 2019), a pesar de la distancia entre la estación y el área de estudio, podemos asumir que las características del viento son similares en ambas zonas. Adicionalmente, con el fin de tener en cuenta la variabilidad de la onda de marea y de manera específica, sus estados (sicigia y cuadratura) y momentos diurnos (creciente, vaciante, pleamar o bajamar), se utilizaron los valores del pronóstico
Wind (strength and direction) and tidal data were analyzed in order to understand the behavior of the currents. The wind data are 1 to $6 \mathrm{~h}$ averages recorded at the Centro de Investigaciones Oceanográfica e Hidrográficas (CIOH) station, located in the northern end of the Gulf of Urabá (Sapzurro, Chocó). Taking into account results that show the spatial variability of the Gulf of Urabá's wind field (Toro et al., 2019), in spite of the distance between the station and the study area, we may assume that both areas share similar wind conditions. Forecast values from the Sapzurro tide gauge (CIOH, 2017) were also used to assess the variability of the tide and specifically, its range (spring or neap) and diurnal phases (rising, ebb, high tide or low tide) (Table 1). All the surveys were conducted with low-wave conditions, 
del mareógrafo de Sapzurro (CIOH, 2017) (Tabla 1). Todas las campañas se realizaron en condiciones de oleaje leve, con la altura de ola incrementándose ligeramente durante las campañas de las épocas de poca lluvia debido a la persistencia de los vientos alisios provenientes del norte (Tabla 1). with wave height increasing slightly during the low rainfall season surveys due to the steady trade winds from the north (Table 1).

Tabla 1. Resumen de mediciones en campo.

Table 1. Summary of field measurements.

\begin{tabular}{|c|c|c|c|c|c|}
\hline \multirow{2}{*}{$\begin{array}{l}\text { Medición de campo / } \\
\text { Field measurement }\end{array}$} & \multirow{2}{*}{$\begin{array}{l}\text { Época climática / } \\
\text { Climatic season }\end{array}$} & \multirow{2}{*}{$\begin{array}{l}\text { Estado de la marea (carrera } \\
\text { de marea) / Tidal state }\end{array}$} & \multirow{2}{*}{$\begin{array}{l}\text { Momento de la marea (hora de inicio y } \\
\text { final del lanzamiento) / Tidal momento } \\
\text { (start and end time of launch) }\end{array}$} & \multicolumn{2}{|c|}{$\begin{array}{l}\text { Condición de viento } \\
\text { / Wind condition }\end{array}$} \\
\hline & & & & Dir & Vel. $(\mathrm{m} / \mathrm{s})$ \\
\hline 1 (12 Nov 2017) & $\begin{array}{l}\text { Mucha lluvia } \\
\text { / Rainy }\end{array}$ & Sicigia / Spring $(0.30 \mathrm{~m})$ & $\begin{array}{l}\text { Vaciante / Ebb (7:00)- } \\
\text { Creciente / Rising (16:30) }\end{array}$ & $\mathrm{N}$ & $1-2$ \\
\hline 2 (18 Nov 2017) & $\begin{array}{l}\text { Mucha lluvia } \\
\text { / Rainy }\end{array}$ & Cuadratura / Neap $(0.15 \mathrm{~m})$ & $\begin{array}{l}\text { Bajamar / Low tide (6:00) - } \\
\text { Bajamar / Low tide (17:10) }\end{array}$ & $\mathrm{N}$ & $1-2$ \\
\hline 3 (24 Enero 2018) & Poca lluvia / Dry & Cuadratura / Neap $(0.13 \mathrm{~m})$ & $\begin{array}{l}\text { Creciente / Rising (7:00) - } \\
\text { Vaciante / Ebb (16:00) }\end{array}$ & SSE & $2-4$ \\
\hline 4 (31 Enero 2018) & Poca lluvia / Dry & Sicigia / $(0.30 \mathrm{~m})$ & $\begin{array}{c}\text { Creciente / Rising (7:00) - } \\
\text { Vaciante / Ebb (16:00) }\end{array}$ & SSE & $2-4$ \\
\hline
\end{tabular}

\section{RESULTADOS}

Las trayectorias de los derivadores superficiales durante las cuatro campañas se muestran en las Figuras 4, 6,8 y 10. La trayectoria de cada derivador está identificada con un número y un color que corresponde a los diferentes lanzamientos. En las Figuras 5, 7, 9 y 11 se presentan los datos de viento (rosas de viento y series temporales vectoriales), elevación del nivel medio del mar y valores de las componentes $(u, v)$ y magnitud de la corriente. A continuación, se analizan por separado las observaciones para las épocas de mucha y de poca lluvia.

Durante la época de mucha lluvia se realizaron dos campañas de medición (12 y 18 de noviembre, 2017) (Figuras 4 y 6). En este periodo el comportamiento del viento fue similar, con vientos débiles hacia el noroccidente a primera hora de la mañana y última hora de la tarde y más intensos hacia el suroriente durante el resto del día, alcanzando $4 \mathrm{~m} / \mathrm{s}$ durante las horas del mediodía (Figuras 5A y 7A).

En la primera campaña (12 de noviembre) las condiciones de marea corresponden a la época de sicigia con una carrera de marea de aproximadamente $0,30 \mathrm{~m}$ (Figura 5C). Se realizaron un total de cuatro lanzamientos. En horas de la mañana se efectuaron los lanzamientos L1 y L2 (Figura 4). En estos casos las trayectorias de los dos derivadores presentaron direcciones contrarias (hacia el sur y norte, respectivamente). El lanzamiento L1 se realizó

\section{RESULTS}

The paths taken by the surface drifters in each of the four rounds are shown in Figures 4, 6, 8 and 10. The path of each drifter is identified with a number and a color corresponding to the different launches. Wind data (wind roses and vector time series), mean sea level rise and water velocity component values $(u, v)$ and magnitude is presented in Figures 5, 7, 9 and 11. The observations for high and low rainfall periods will be analyzed separately below.

Two measurement rounds were conducted during the rainy season (November 12 and 18, 2017) (Figures 4 and 6). Wind conditions were similar over the whole period, with low winds to the northwest in the early morning and late afternoon and higher winds to the southeast during the rest of the day, reaching $4 \mathrm{~m} / \mathrm{s}$ around midday (Figures $5 \mathrm{~A}$ and 7A).

The first round of measurements (November 12) took place during spring tide, with a tidal range of approximately $0.30 \mathrm{~m}$ (Figure 5B). A total of four launches were carried out. In the morning, drifters L1 and L2 were launched (Figure 4). The two drifters moved in opposite directions (to the south and north, respectively). L1 was released just before high tide, with conditions of weak winds $(1.75 \mathrm{~m} / \mathrm{s})$ towards the northwest (Figure 5B). The direction of the current was southeast, towards the interior of Turbo bay, with an average speed of $0.3 \mathrm{~m} / \mathrm{s}$ (Figures $5 \mathrm{D}$ and $5 \mathrm{E}$ ). 
justo antes de la pleamar, con condiciones de viento débil $(1,75 \mathrm{~m} / \mathrm{s})$ hacia el noroccidente (Figura $5 \mathrm{~B})$. En este caso la dirección de la corriente fue suroriente, hacia el interior de bahía Turbo, con una velocidad promedio de $0,3 \mathrm{~m} / \mathrm{s}$ (Figura 5D y 5E). El segundo lanzamiento (L2) tuvo lugar durante un periodo de vaciante con vientos intensos $(3 \mathrm{~m} / \mathrm{s})$ y dirigidos hacia el suroriente (Figura 5B). En este caso la corriente se dirigió hacia el norte, con velocidades entre 0,05 y $0,10 \mathrm{~m} / \mathrm{s}$ (Figura $5 \mathrm{D}$ y $5 \mathrm{E}$ ).
The second release (L2) took place while the tide was going out during a period of strong winds $(3 \mathrm{~m} / \mathrm{s})$ blowing to the southeast (Figure 5B). In this case, the direction of current was to the north, with velocities between 0.05 and $0.10 \mathrm{~m} / \mathrm{s}$ (Figures 5D and 5E).

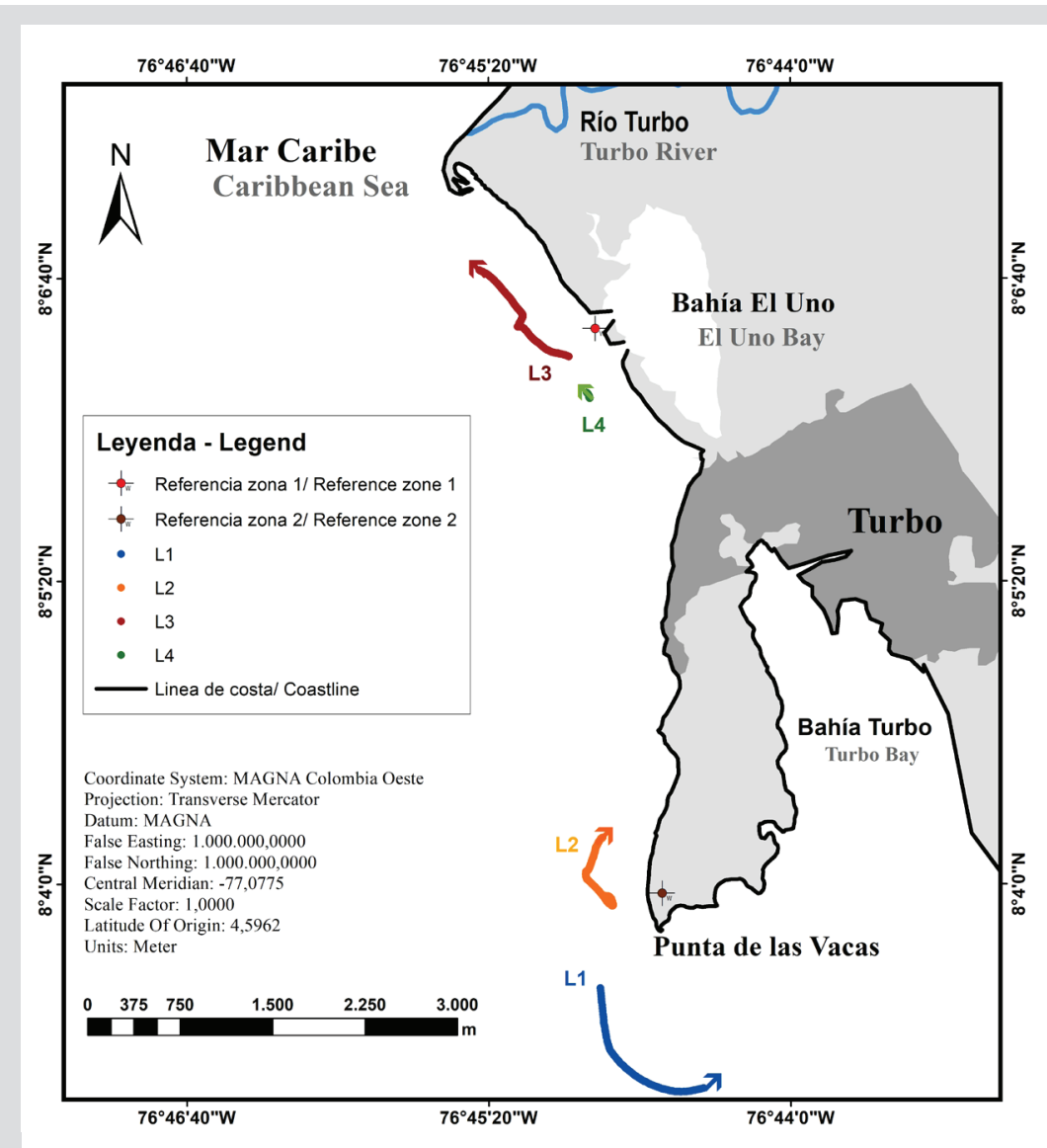

Figura 4. Campaña 1: 12 de noviembre de 2017, época de mucha lluvia. Trayectorias de los cuatro lanzamientos de derivadores: L1, L2, L3 y L4.
Figure 4. Round 1: November 12, 2017, rainy season. Paths for the four drifter launches: L1, L2, L3 and L4.
El 12 de noviembre en horas de la tarde se realizaron los lanzamientos L3 y L4 (Figura 4). Para estos dos lanzamientos la dirección del viento era hacia el suroriente con una magnitud promedio de $4 \mathrm{~m} / \mathrm{s}$ (Figura 5B). El lanzamiento L3 estuvo cerca de bajamar (Figura $5 \mathrm{C}$ ), observándose una corriente hacia el noroccidente con velocidades entre 0,3 y $0,4 \mathrm{~m} / \mathrm{s}$ (Figura $5 \mathrm{D}$ y E). En el caso de L4, realizado durante marea creciente (Figura 5C), la corriente nuevamente fue hacia el norte con magnitudes menores a L3 entre 0,05 y $0,10 \mathrm{~m} / \mathrm{s}$ (Figura $5 \mathrm{D}$ y E).
Drifters L3 and L4 were launched on November 12 in the afternoon (Figure 4). For these two launches the wind direction was to the southeast with an average speed of $4 \mathrm{~m} / \mathrm{s}$ (Figure 5B). Launch L3 was near low tide (Figure 5C), and showed a northwesterly current with velocities of between 0.3 and $0.4 \mathrm{~m} / \mathrm{s}$ (Figure 5D and E). In the case of L4, released during a rising tide (Figure $5 \mathrm{C}$ ), the current was again northward but weaker than L3 with speeds between 0.05 and $0.10 \mathrm{~m} / \mathrm{s}$ (Figure 5D and E). 


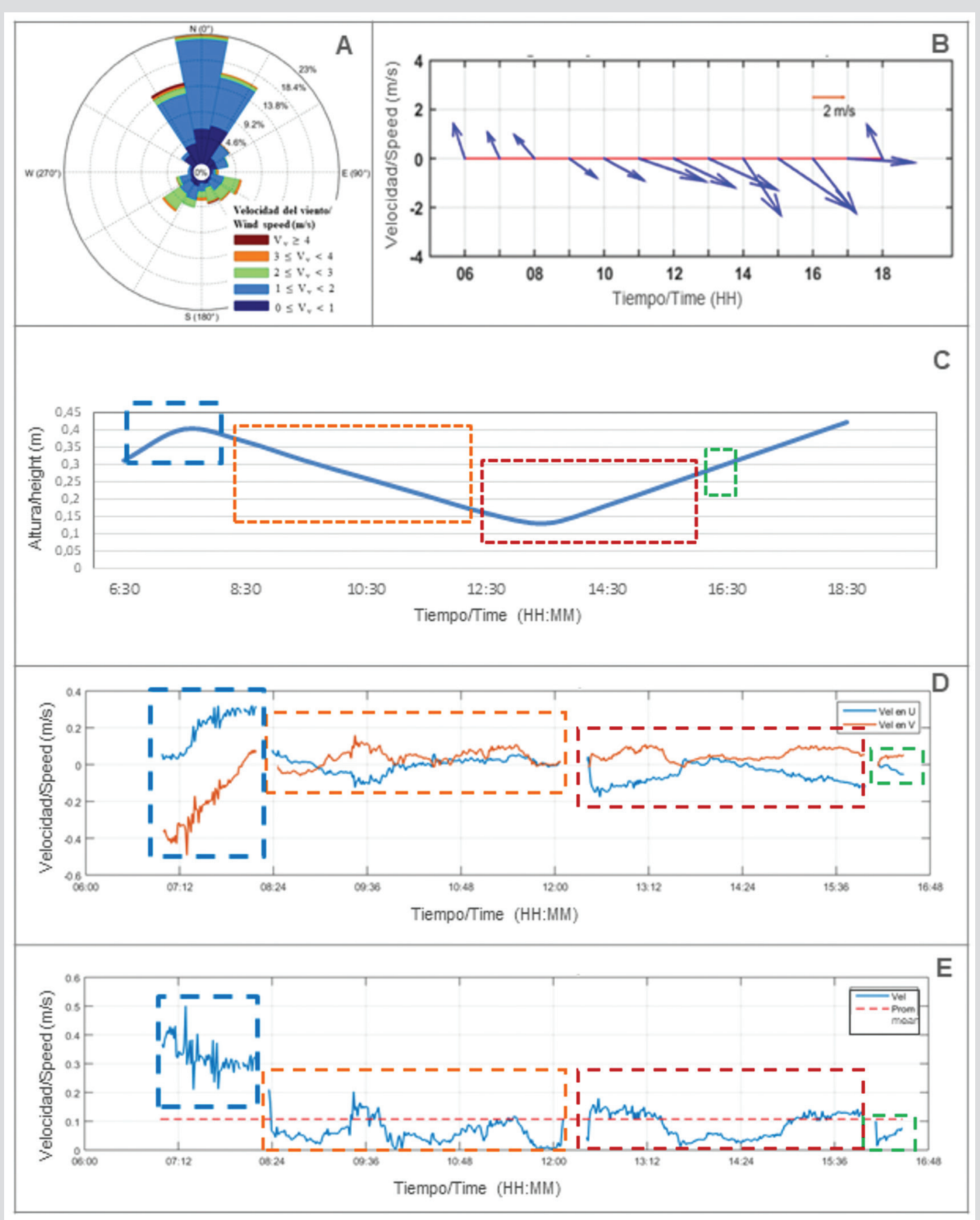

Figura 5. Campaña 1: 12 de noviembre de 2017, época de mucha lluvia. Medidas in situ de la magnitud y dirección del viento: (A) rosa de viento y (B) serie vectorial del viento. (C) Nivel de la marea. (D) Componentes zonal y meridional de la corriente. (E) Magnitud de la corriente. Los colores de los recuadros en (C), (D) y (E) coinciden con los de las trayectorias en la Figura 4.
Figure 5. Round 1: November 12, 2017, rainy season. In situ measurements of the wind speed and direction: (A) wind rose and (B) wind vector series. (C) Tide level. (D) Zonal and meridional current components. (E) Current magnitude. The box colors in (C), (D) and (E) match those of the paths in Figure 4.
La segunda campaña se hizo el 18 de noviembre de 2017, con un total de cuatro lanzamientos (Figura 6). En esta campaña la marea se encontraba en cuadratura, con una carrera de marea de aproximadamente $0,15 \mathrm{~m}$ (Figura 7C). En las horas de la mañana, los lanzamientos L1 y L2
The second round was carried out on November 18,2017 , with a total of four launches (Figure 6). During this round there was a neap tide, with a tidal range of approximately $0.15 \mathrm{~m}$ (Figure 7C). L1 and L2 were launched in the morning with the drifters starting around 
se realizaron con los derivadores separados apenas unos $100 \mathrm{~m}$. En el momento del lanzamiento la marea era llenante y el viento con dirección variable (hacia el nororiente, migrando hacia el occidente hasta alcanzar dirección hacia el suroriente) y magnitud promedio de $1,75 \mathrm{~m} / \mathrm{s}$ (Figura 7B). Ambos derivadores siguieron una trayectoria muy similar durante aproximadamente $5 \mathrm{~h}$. Inicialmente la dirección de la corriente fue hacia occidente con magnitudes $<0,05$ $\mathrm{m} / \mathrm{s}$. Luego la magnitud incremento hasta $0,15 \mathrm{~m} / \mathrm{s}$ en dirección noroccidente (Figuras 7D y 7E). Es de notar que este incremento en la magnitud de la velocidad coincidió con un aumento de los vientos del noroccidente, es decir la corriente viajó en dirección opuesta a los vientos (Figura 7). only $100 \mathrm{~m}$ apart. At the time of the launch, the tide was high and the wind direction varied (to the northeast, shifting to the west until it reached a southeasterly direction) with an average speed of $1.75 \mathrm{~m} / \mathrm{s}$ (Figure 7B). Both drifters followed a very similar path for approximately $5 \mathrm{~h}$. Initially the direction of the current was westward with magnitudes $<0.05 \mathrm{~m} / \mathrm{s}$. Then the magnitude increased to $0.15 \mathrm{~m} / \mathrm{s}$ in a northwesterly direction (Figures 7D and 7E). It is important to note that this increase in velocity coincided with an increase in the speed of northwesterly winds, i.e., the current flowed in the opposite direction to the wind (Figure 7).

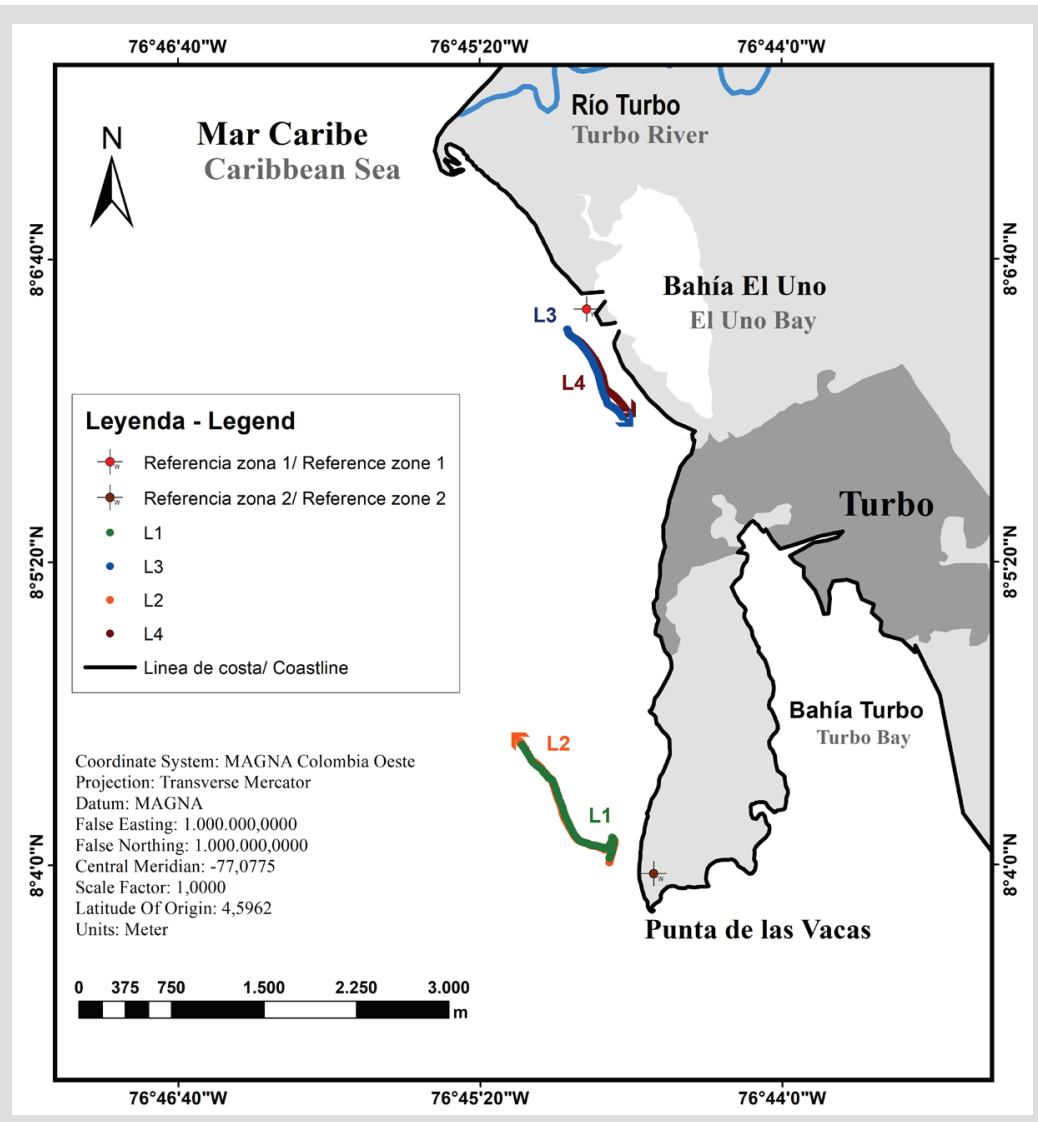

Figura 6. Campaña 2: 18 de noviembre de 2017, época de mucha lluvia. Trayectorias de los cuatro lanzamientos de derivadores: L1, L2, L3 y L4.

Figure 6. Round 2: November 18, 2017, rainy season. Paths for the four drifter launches: L1, L2, L3 and L4.
El 18 de noviembre en las horas de la tarde se realizaron los lanzamientos L3 y L4, de nuevo con los derivadores en posiciones cercanas. En este caso la marea se encontraba bajando y la dirección del viento era hacia el suroriente con una magnitud promedio de $2,5 \mathrm{~m} / \mathrm{s}$ (Figura 7B). Nuevamente, los derivadores mantuvieron un recorrido similar, cercano a la línea de costa. En este caso las corrientes
L3 and L4 were launched in the afternoon on November 18, again with the drifters starting close together. At this time, the tide was going out and the wind direction was to the southeast with an average speed of $2.5 \mathrm{~m} / \mathrm{s}$ (Figure 7B). Again, the drifters kept to a similar path, close to the coastline. They showed that the currents were to the southeast, with a velocity that initially decreased from 0.07 
asociadas fueron hacia el suroriente, con una velocidad que inicialmente disminuyó de 0,07 a $0,03 \mathrm{~m} / \mathrm{s}$ y se incrementó hacia el final del periodo, alcanzando $0,15 \mathrm{~m} / \mathrm{s}$ (Figuras 7D y 7E). En este caso la corriente estaba en la misma dirección del viento; sin embargo, la corriente aumentó su magnitud precisamente cuando el viento se debilitó (Figura 7). to $0.03 \mathrm{~m} / \mathrm{s}$ and increased towards the end of the period, reaching $0.15 \mathrm{~m} / \mathrm{s}$ (Figures $7 \mathrm{D}$ and $7 \mathrm{E}$ ). The current flowed in the same direction as the wind, however, the current increased in magnitude precisely when the wind weakened (Figure 7).
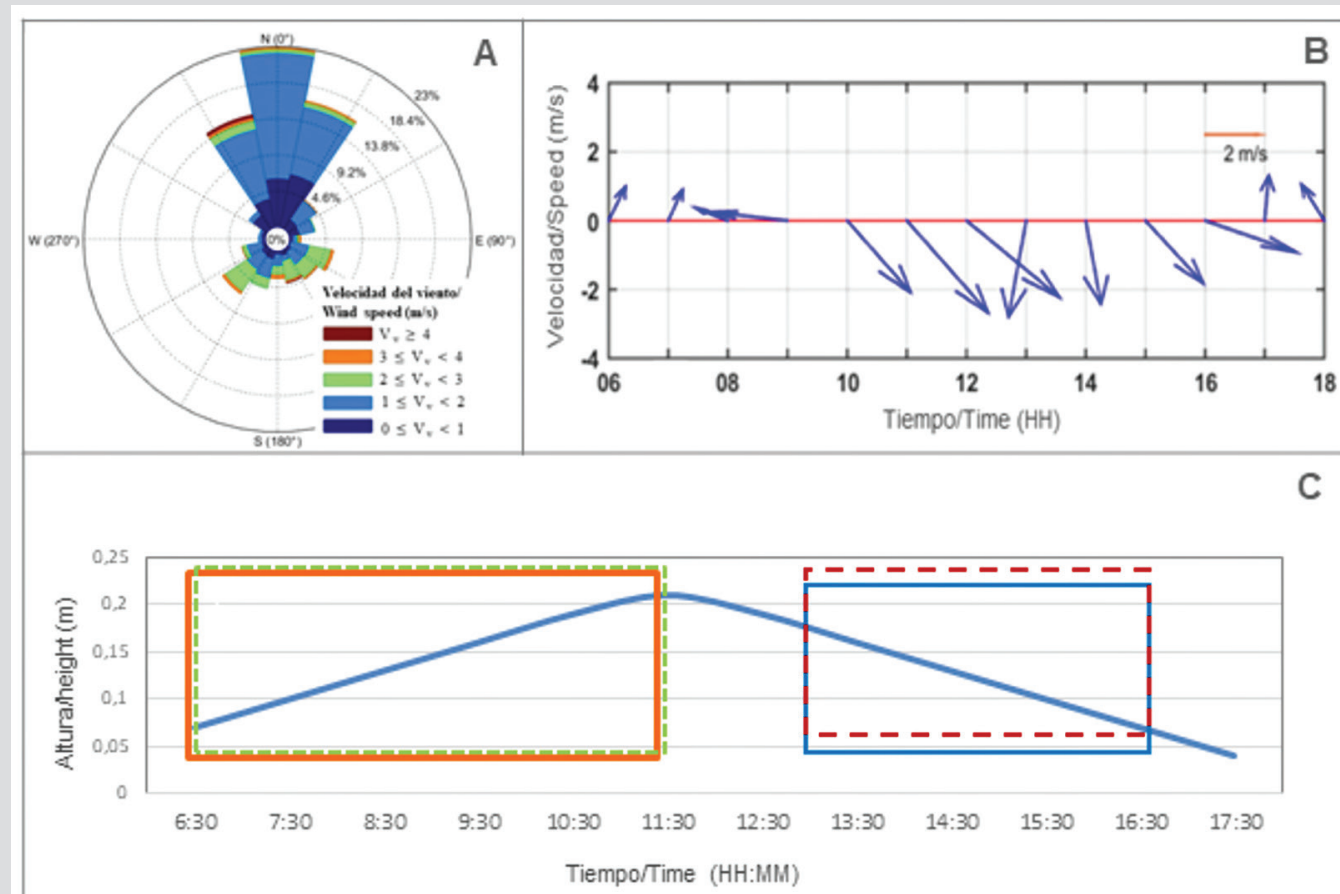

C
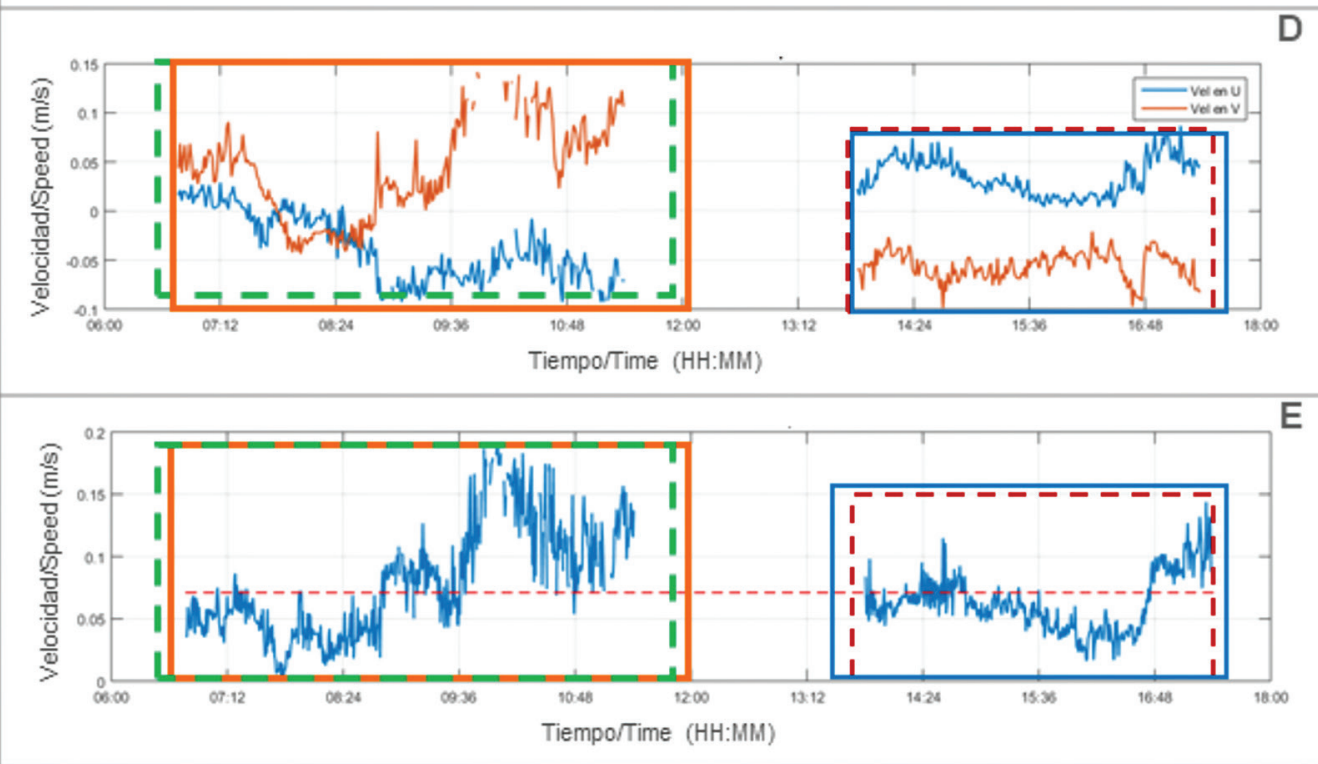

Figura 7. Campaña 2: 18 de noviembre de 2017, época de mucha lluvia. Medidas in situ de la magnitud y dirección del viento: (A) rosa de viento y (B) serie vectorial del viento. (C) Nivel de la marea. (D) Componente zonal y meridional de la corriente. (E) Magnitud de la corriente. Los colores de los recuadros en (C), (D) y (E) coinciden con los de las trayectorias en la Figura 6.
Figure 7. Round 2: November 18, 2017, rainy season. In situ measurements of the wind speed and direction: (A) wind rose and (B) wind vector series. (C) Tide level. (D) Zonal and meridional current components. (E) Current magnitude. The box colors in (C), (D) and (E) match those of the paths in Figure 6. 
En la época de poca lluvia se realizaron las otras dos campañas (24 y 31 de enero de 2018, respectivamente) (Figuras 8 y 10). En ambos casos el comportamiento del viento fue similar, con una componente predominante hacia el sur y magnitudes entre 2 y $4 \mathrm{~m} / \mathrm{s}$ (Figuras 9A y 11A).
The other two rounds were carried out during the dry season (January 24 and 31, 2018, respectively) (Figures 8 and 10). The wind behavior was similar for both launches, with a predominant southerly component and speeds between 2 and $4 \mathrm{~m} / \mathrm{s}$ (Figures 9A and 11A).

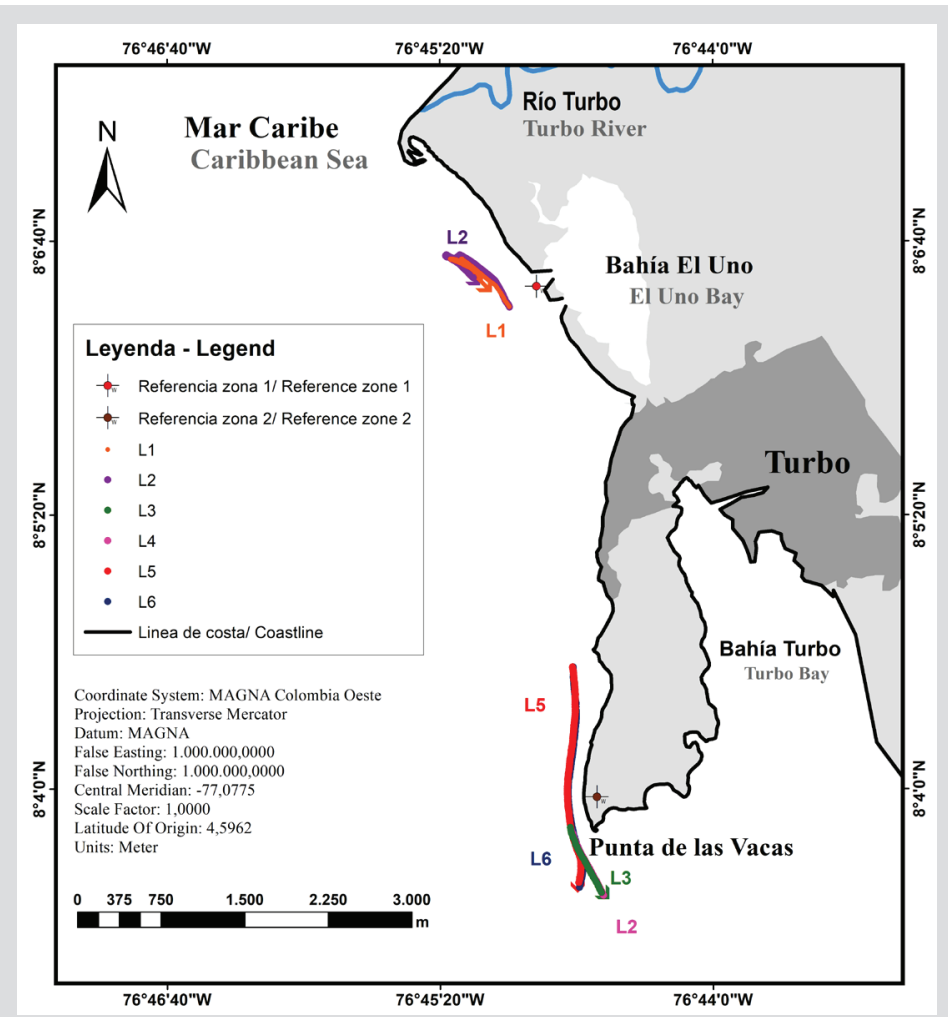

Figura 8. Campaña 3: 24 de enero de 2018, época de poca lluvia. Trayectorias de los seis lanzamientos de derivadores: L1, L2, L3, L4, L5 y L6.
Figure 8. Round 3: January 24, 2018, dry season. Paths for the six drifter launches: L1, L2, L3, L4, L5 and L6.
Durante la tercera campaña la condición de marea era de tipo cuadratura, con una carrera de marea de $0,13 \mathrm{~m}$ (Figura 9C). En las horas de la mañana, se lanzaron los derivadores L1 y L2 en posiciones cercanas ( $<100$ m de separación). En este caso la marea estaba en vaciante y el viento tenía una dirección predominante hacia el sur y magnitud promedio de $4 \mathrm{~m} / \mathrm{s}$ (Figuras 9 B y C). Los derivadores trazaron una trayectoria similar durante $5 \mathrm{~h}$. Las corrientes asociadas inicialmente fueron hacia el noroccidente $(0,1 \mathrm{~m} / \mathrm{s})$ y luego súbitamente cambiaron de dirección y se dirigieron hacia el suroriente $(0,05 \mathrm{~m} / \mathrm{s})$ (Figuras 9D y 9E).

Durante la campaña 3, en horas de la tarde, se hicieron los lanzamientos de los derivadores L3 a L6. En este caso la marea estaba cercana a la bajamar y el viento mantenía una dirección predominante hacia el suroriente,
The third round took place during a neap tide, with a tidal range of $0.13 \mathrm{~m}$ (Figure 9C). The L1 and L2 drifters were launched in the morning at positions close to each other $(<100 \mathrm{~m}$ apart). In this case the tide was going out and the wind had a predominant southerly direction and average speed of $4 \mathrm{~m} / \mathrm{s}$ (Figures $9 \mathrm{~B}$ and $9 \mathrm{C}$ ). The drifters followed similar paths for $5 \mathrm{~h}$. The currents were initially to the northwest $(0.1 \mathrm{~m} / \mathrm{s})$ and then suddenly changed direction to the southeast $(0.05 \mathrm{~m} / \mathrm{s})$ (Figures 9D and 9E).

Round 3 took place during the afternoon, when drifters L3 to L6 were launched. It was close to low tide and the wind kept to a predominant southeasterly direction, with an average speed of $3.75 \mathrm{~m} / \mathrm{s}$. After the L3 and L4 drifters were launched, they were pulled to the southeast and quickly left the study area. For this reason, L5 and L6 were launched further to the north during high tide, although it 
con una magnitud promedio de $3,75 \mathrm{~m} / \mathrm{s}$. Inicialmente se lanzaron los derivadores L3 y L4, que se desplazaron hacia el suroriente saliéndose rápidamente del área de estudio. Por tal motivo se realizaron los lanzamientos L5 y L6 desde una posición más al norte ya durante la marea llenante, aunque fue de mínima amplitud (3 cm) (Figura 9C). En este caso la corriente tomo una dirección hacia el sur con un valor promedio de $0,2 \mathrm{~m} / \mathrm{s}$ (Figuras 8 y 9D). was at minimum amplitude $(3 \mathrm{~cm})$ (Figure 9C). For these launches the current flowed in a southerly direction with an average speed of $0.2 \mathrm{~m} / \mathrm{s}$ (Figures 8 and 9D).
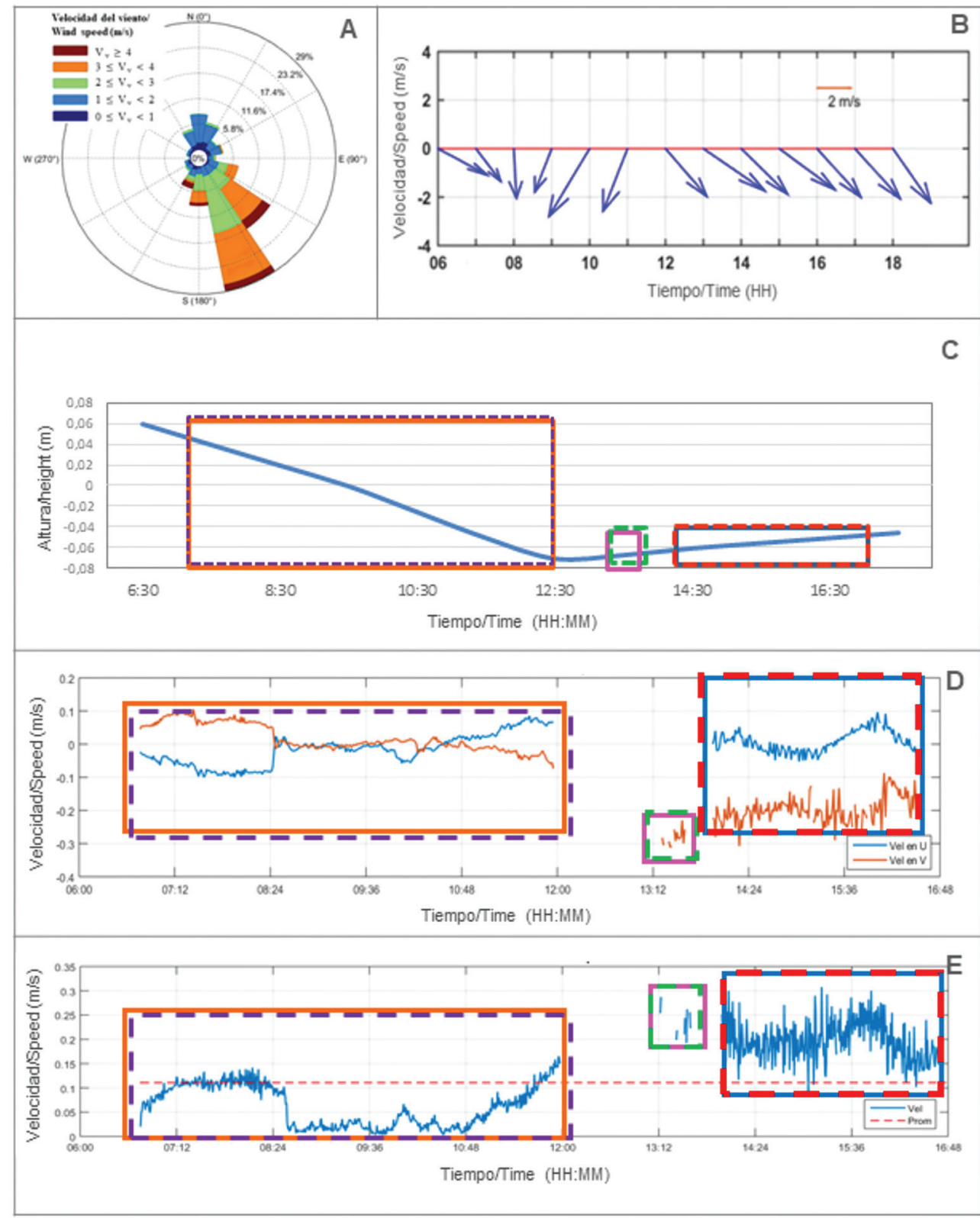

Figura 9. Campaña 3: 24 de enero de 2018, época de poca lluvia. Medidas in situ de la magnitud y dirección del viento: (A) rosa de viento y (B) serie vectorial del viento. (C) Nivel de la marea. (D) Componente zonal y meridional de la corriente. (E) Magnitud de la corriente. Los colores de los recuadros en (C), (D) y (E) coinciden con los de las trayectorias mostradas en la Figura 8.
Figure 9. Round 3: January 24, 2018, dry season. In situ measurements of wind speed and direction: (A) wind rose and (B) wind vector series. (C) Tide level. (D) Zonal and meridional current components. (E) Current magnitude. The box colors in (C), (D) and (E) match those of the paths in Figure 8. 
Finalmente, la cuarta campaña (31 de enero, 2018) fue realizada durante una época de sicigia, con una carrera de marea de aproximadamente $0,3 \mathrm{~m}$ (Figura 11C). En las horas de la mañana, el primer lanzamiento (L1) se realizó con la marea creciente (Figura 11C) y con viento proveniente de noroccidente y una magnitud promedio de 4,25 m/s (Figura 11B). El derivador viajó en dirección sur saliéndose rápidamente del área de estudio, por lo cual se hizo un segundo lanzamiento (L2) que tomó la misma dirección, acercándose a la línea de costa. En ambos casos las corrientes asociadas a los derivadores presentaron valores bajos entre 0,06 y $0,09 \mathrm{~m} / \mathrm{s}$ (Figuras $11 \mathrm{D}$ y $11 \mathrm{E}$ ). En las horas de la tarde, solo se realizó un lanzamiento (L3), con la marea vaciante (Figura 11C) y con viento en dirección hacia el suroriente con magnitud promedio de 5,5 $\mathrm{m} / \mathrm{s}$. En este caso la corriente mostró una dirección hacia el suroriente, con una magnitud que disminuyó de 0,12 a 0,04 $\mathrm{m} / \mathrm{s}$ (Figura 11E).
Finally, the fourth round (January 31, 2018) was carried out during a spring tide, with a tidal range of approximately $0.3 \mathrm{~m}$ (Figure 11C). The first drifter (L1) was launched in the morning on a rising tide (Figure 11C) and with northwesterly winds with an average speed of $4.25 \mathrm{~m} / \mathrm{s}$ (Figure 11B). The drifter traveled in a southerly direction and quickly left the study area, so a second drifter (L2) was launched which was pulled in the same direction, approaching the coastline. Both drifters recorded currents of low magnitude; between 0.06 and $0.09 \mathrm{~m} / \mathrm{s}$ (Figures 11D and 11E). In the afternoon, only one drifter (L3) was launched, with the tide going out (Figure 11C) and with wind direction towards the southeast with an average speed of $5.5 \mathrm{~m} / \mathrm{s}$. In this case the current flowed in a southeasterly direction, with speed that decreased from 0.12 to $0.04 \mathrm{~m} / \mathrm{s}$ (Figure 11E).

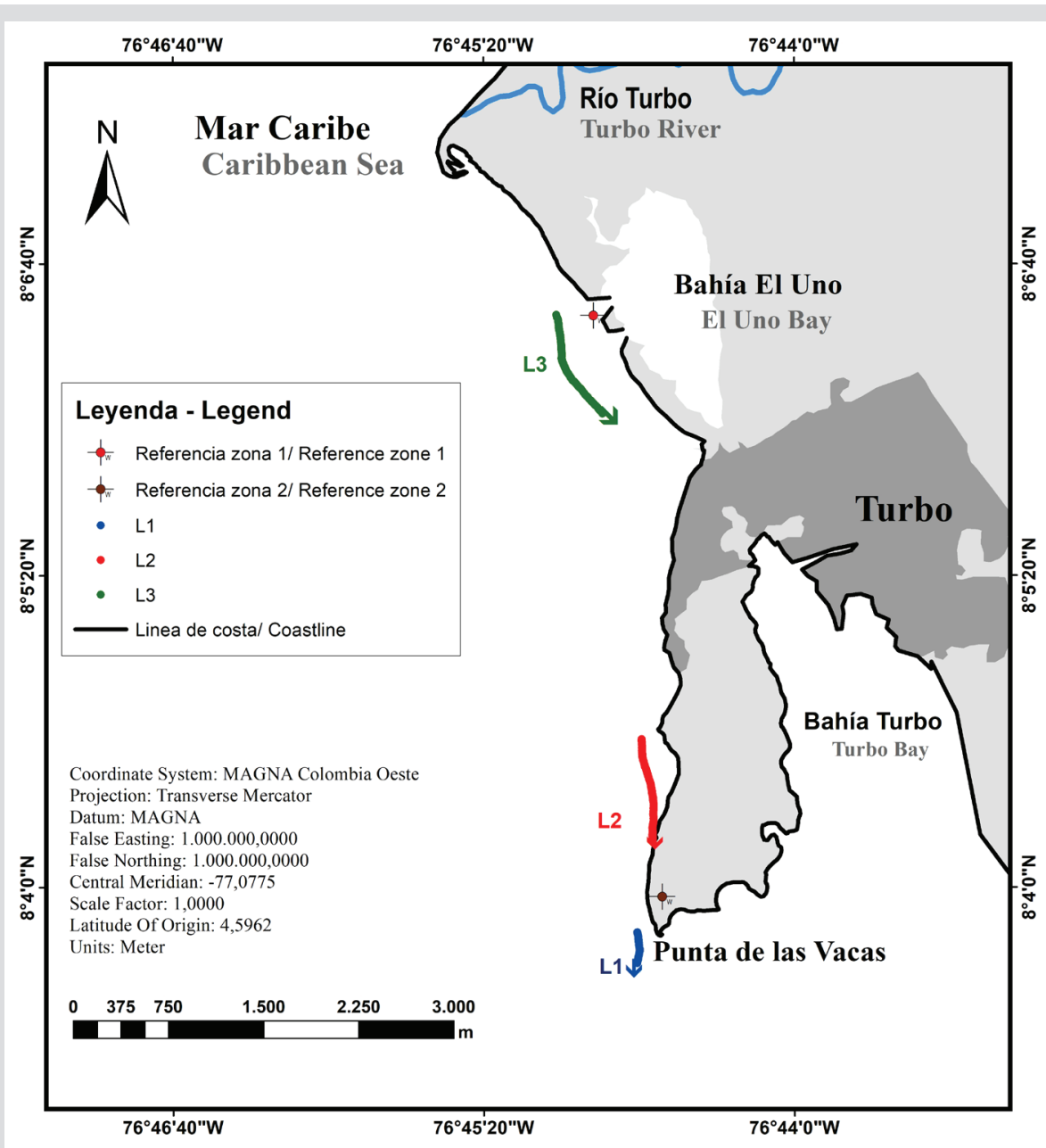

Figura 10. Campaña 4: 31 de enero de 2018, época de poca lluvia. Trayectorias de los tres lanzamientos de derivadores: L1, L2 y L3.
Figure 10. Round 4: January 31, 2018, dry season. Paths for the three drifter launches: L1, L2 and L3. 


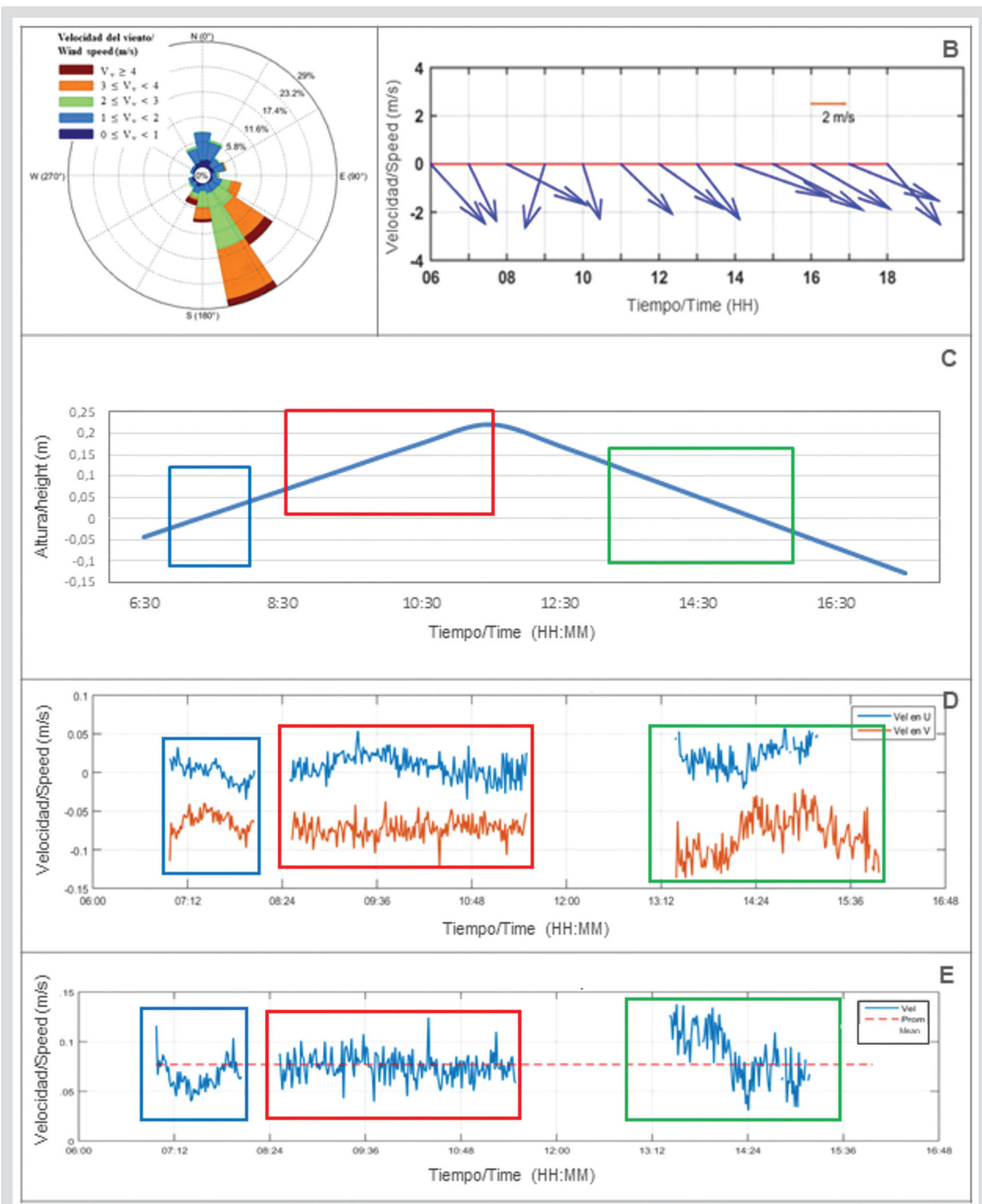

Figura 11. Campaña 4: 31 de enero de 2018, época de poca lluvia. Medidas in situ de la magnitud y dirección del viento: (A) rosa de viento y (B) serie vectorial del viento. (C) Nivel de la marea. (D) Componente zonal y meridional de la corriente. (E) Magnitud de la corriente. Los colores de los recuadros en (C), (D) y (E) coinciden con los de las trayectorias mostradas en la Figura 10.
Figure 11. Round 4: January 31, 2018, dry season. In situ measurements of the wind speed and direction: (A) wind rose and (B) wind vector series. (C) Tide level. (D) Zonal and meridional current components. (E) Current magnitude. The box colors in (C), (D) and (E) match those of the paths in Figure 10. 


\section{DISCUSIÓN}

Las campañas realizadas han tenido como objetivo el análisis del patrón de corrientes costeras en función de la variación de la onda marea y del viento. El área de estudio, localizada en el margen suroriental del golfo de Urabá, a lo largo de unos $6 \mathrm{~km}$ de costa entre punta Yarumal y Punta de Las Vacas, se dividió en dos sectores. En cada uno de estos se lanzaron dos derivadores superficiales en las dos épocas climáticas del año, de poca lluvia (seca) y de mucha lluvia (húmeda), y las trayectorias fueron analizadas conjuntamente con los vientos superficiales y el ciclo de marea con el fin de determinar los procesos y patrones dominantes de circulación superficial.

El comportamiento de la corriente de marea en el golfo de Urabá, como cuerpo semicerrado de agua, es consistente con el de una onda estacionaria. La onda de marea incidente y reflejada se combinan de modo que la velocidad se hace cero en la cabeza del golfo (antinodo) y máxima a cierta distancia de la cabeza, donde se localizaría la amplitud mínima de la marea (nodo). Para un golfo rectangular de profundidad constante $H$ esta distancia viene dada por $\boldsymbol{T}(\boldsymbol{g H})^{1 / 2} / 4$, donde $T$ es el periodo de la marea (Proudman, 1953; Godin, 1993). En el caso de la componente semidiurna dominante (M2), y considerando profundidades entre $20 \mathrm{y}$ $40 \mathrm{~m}$, esto corresponde a una distancia de entre 158 y 224 $\mathrm{km}$. Estas distancias son mayores que la longitud del golfo de Urabá, por lo que cabe esperar que no hay ningún nodo dentro del golfo y que la marea oscilará aproximadamente en fase dentro de todo el golfo (si se ignoran los efectos de rotación y fricción, y se supone que la velocidad de propagación de la onda no está limitada por la profundidad del agua del golfo).

Durante las campañas 1 y 3 , el patrón de la corriente es coherente con el ciclo de marea en el que se hicieron las mediciones. En la campaña 1, con marea creciente, la corriente asociada al lanzamiento L1 fue hacia el sur, es decir siguiendo la dirección del agua que entra al golfo e incluso a la bahía Turbo. Durante la campaña 3, con marea en llenante, la corriente asociada a los lanzamientos L3, L4, L5 y L6 fueron hacia el sur, correspondiente al agua que entra al golfo. Sin embargo, se aprecia que las corrientes observadas ocurren con un desfase temporal con respecto a las corrientes esperadas para una onda de marea estacionaria, ya que las velocidades mínimas (cerca de pleamar y bajamar) y las máximas (en llenante y vaciante) ocurren más tarde de lo esperado.

\section{DISCUSSION}

The rounds of measurements were carried out to analyze the pattern of coastal currents in relation to the variation of the tide and the wind. The study area, located on the southeastern shore of the Gulf of Urabá, along about $6 \mathrm{~km}$ of coastline between Yarumal spit and Las Vacas spit, was divided into two sectors. In each of these, two surface drifters were launched in both seasons of the year, low rainfall (dry) and high rainfall (wet), and the paths they took were analyzed together with the surface winds and the tidal cycle in order to determine the dominant surface circulation processes and patterns.

The way that the tidal current behaves in the Gulf of Urabá, being a semi-enclosed body of water, is consistent with that of a standing wave. The incident and reflected tidal wave combine, so that the standing wave has zero amplitude at the head of the Gulf (antinode) and maximum amplitude at a certain distance from the head, where the minimum tidal amplitude (node) would be located. For a rectangular gulf of constant depth $H$ this distance is given by $\boldsymbol{T}(\boldsymbol{g H})^{1 / 2} / 4$, where $T$ is the tidal period (Proudman, 1953; Godin, 1993). In the case of the dominant semidiurnal component (M2), and considering water depths between 20 and $40 \mathrm{~m}$, this corresponds to lengths between 158 and $224 \mathrm{~km}$. These distances are greater than the length of the Gulf of Urabá, so it can be expected that the node does not lie within the Gulf and that the tide will oscillate approximately in phase within the entire Gulf (if rotation and friction effects are ignored, and it is assumed that the wave propagation velocity is not limited by the depth of water in the Gulf).

During rounds 1 and 3, the current pattern is consistent with the tidal cycle in which the measurements were made. In round 1 , when the tide was rising, the current pulled the L1 drifter southward, i.e., it followed the direction of the water entering the Gulf and even Turbo bay itself. During round 3, at high tide, the L3, L4, L5 and L6 drifters were pulled southward by the current, in the same direction as the water entering the Gulf. However, these observed currents lag behind the current expected for a standing tidal wave, as the minimum velocities (near high and low tide) and maximum velocities (at full and neap tide) occur later than expected.

The time lag of the currents behind the predicted tide can be explained by the distance between the study area and the location of the tide gauge (Sapzurro), which 
El desfase temporal de las corrientes con respecto a la marea predicha puede explicarse debido a la distancia que hay entre el área de estudio y la ubicación del mareógrafo (Sapzurro), el cual se encuentra aproximadamente a $90 \mathrm{~km}$ de distancia del área de estudio. Ignorando todos los factores locales (geometría del golfo, fricción del fondo, descarga de los ríos), podemos suponer que la velocidad de propagación de la fase de la marea en aguas someras viene dada por $\boldsymbol{V}(\boldsymbol{g} \boldsymbol{H})^{1 / 2}$, donde $g$ es la aceleración de la gravedad y $H$ es la profundidad del agua. Por tanto, en profundidades entre 15 y $25 \mathrm{~m}$ la fase de la onda de marea tarda aproximadamente $2 \mathrm{~h}$ en propagarse entre Sapzurro y Turbo. Este desfase también fue registrado por Higuita y Quintana (2020), pudiendo ser acentuado por la batimetría y forma irregular del golfo de Urabá.

En cuanto a la influencia del viento, las corrientes durante las campañas 2 y 4 no tienen una aparente relación con la onda de marea, pero sí con la dirección del viento. En la campaña 2, correspondiente a la época de mucha lluvia y vientos alisios más débiles, el patrón de corrientes parece guardar cierta correlación con la variabilidad diurna de los vientos, en particular con las corrientes frente a Punta de Las Vacas (hacia occidente) y frente a la bahía El Uno (hacia el sur). En la campaña 4, en época de poca lluvia, se presentaron vientos intensos del noroccidente durante todo el día y las corrientes se dirigieron hacia el sur. Este comportamiento es coherente con la fase de la marea durante los dos primeros lanzamientos, pero no durante el tercero, realizado frente a la bahía El Uno. Estos resultados apuntan a la importancia de los vientos como factores generadores de la corriente (Toro et al., 2019).

A pesar de que en época de poca lluvia la magnitud del viento fue mayor que durante la de mucha lluvia, la magnitud de las corrientes fue similar o incluso menor. Esto es probablemente debido a que la marea y el viento tuvieron efectos opuestos. Además, cabe destacar que el efecto del viento puede ser directo, debido al arrastre de los vientos, o indirecto, asociado a la marea meteorológica. La respuesta directa corresponde al arrastre del viento sobre las capas más superficiales de la columna de agua, un efecto que varía con la profundidad. En tanto este estudio utilizó derivadores superficiales (entre 0,5 y $1,5 \mathrm{~m}$ de profundidad), el viento fundamentalmente los arrastra en su misma dirección (en el hemisferio norte, se ha observado experimentalmente y en el laboratorio una desviación hacia la derecha de unos $10^{\circ}$, ver por ejemplo Wu, 1983).

Por otro lado, cerca de la costa, los vientos muestran una oscilación diurna asociada a las brisas mar- is approximately $90 \mathrm{~km}$. Ignoring all local factors (gulf geometry, bottom friction, river outflow), we can assume that the propagation velocity of the tidal phase propagation in shallow water is given by $\boldsymbol{V}(\boldsymbol{g H})^{1 / 2}$, where $g$ is the acceleration of gravity and $H$ is the water depth. Therefore, at depths between 15 and $25 \mathrm{~m}$ the tidal wave phase takes approximately $2 \mathrm{~h}$ to propagate between Sapzurro and Turbo. This lag was also recorded by Higuita and Quintana (2020), and may be exacerbated by the bathymetry and irregular shape of the Gulf of Urabá.

With respect to the effect of winds, the currents recorded during rounds 2 and 4 have no apparent relationship with the tidal wave, but are related to wind direction. In round 2, carried out in the rainy season with weak trade winds, the pattern of currents seems to be correlated with the diurnal variability of the winds, particularly with the currents off Las Vacas spit (to the west) and off El Uno bay (to the south). In round 4, during the dry season, there were strong northwesterly winds throughout the day and the currents flowed to the south. This motion is consistent with the tidal phase during the first two launches, but not during the third, off El Uno bay. These results point to the importance of winds in driving the currents (Toro et al., 2019).

Although the wind speed was higher during the dry season than during the rainy season, the magnitude of the currents was similar or even lower. This is probably because the tide and wind had opposite effects. It should also be noted that the effect of wind can be direct, due to wind drag, or indirect, associated with the meteorological tide. The direct response corresponds to wind drag on the shallowest layers of the water column, an effect that varies with depth. Since this study used shallow drifters (between 0.5 and $1.5 \mathrm{~m}$ depth), they are dragged in essentially the same direction as the wind (in the northern hemisphere, a rightward drift of about $10^{\circ}$ has been observed experimentally and in the laboratory, see for example, $\mathrm{Wu}$, 1983).

Meanwhile, near the coast, there are wind diurnal oscillations associated with sea-land breezes, directed offshore (towards the center of the Gulf, almost perpendicular to the coastline) during the night and onshore during the day, as shown by Arroyo (2019) in his hodograms for the Urabá region. This oscillation is very clear in the rainy season, while the trade winds are weak, and is less evident in the dry season, when the trade winds intensify (Figures 3, 5, 7 and 9). Therefore, in the 
tierra, que se dirigen mar afuera (hacia el centro del golfo, casi perpendicular a la línea de costa) durante las horas nocturnas y hacia el continente en las horas diurnas, tal como lo muestra Arroyo (2019) en sus hodogramas para la región de Urabá. Esta oscilación es muy clara en la época de mucha lluvia, en tanto que los vientos alisios son débiles, y es menos evidente en la época de poca lluvia, cuando los vientos alisios se intensifican (Figuras 3, 5, 7 y 9). Por tanto, en el golfo de Urabá cabe esperar que las brisas mar-tierra se dirijan hacia la cabeza del golfo durante el día y hacia la boca del golfo durante las horas nocturnas (Arroyo, 2019). El resultado será un ciclo meteorológico de $24 \mathrm{~h}$ en la parte interior del golfo, con una aumento en horas de la tarde y una descenso a primeras horas de la mañana en el nivel medio del mar. Este ciclo se encontraría aproximadamente en fase con la marea astronómica durante la campaña 3 y fuera de fase en las otras campañas. Estos resultados coinciden con lo registrado por Toro et al. (2019) para ciertos momentos del año en el golfo de Urabá, donde las direcciones del viento y las corrientes están en fase, específicamente durante octubre y diciembre con vientos del sur y corrientes más intensas.

Sobre otros factores, las observaciones aquí presentadas muestran que tantola variación de la onda demarea como la intensidad del viento tienen un efecto importante sobre las corrientes costeras de la región, pero también apuntan a la necesidad de tomar en cuenta otros factores en la modificación del patrón de corrientes y en el desfase de la onda de marea. Entre estos factores probablemente destacan las lagunas costeras adyacentes, como las bahías El Uno y Turbo. Ambas geoformas están asociadas a las espigas litorales derivadas de la desembocadura del río Turbo, creando cuerpos de agua semicerrados que intensifican el efecto de la marea, principalmente en términos de la velocidad en los momentos de vaciante o llenante.

Los resultados sugieren un desfase en el comportamiento del derivador L1 (campaña 1), lanzado cerca de Punta de Las Vacas en condiciones de viento y oleaje mínimas, que se dirigió hacia el interior de la bahía de Turbo (Figura 4). Otros ejemplos son el comportamiento de los derivadores L3 y L4 (campaña 2) y L3 (campaña 4), lanzados justo frente a la bahía El Uno en momentos en que la marea estaba en vaciante; las corrientes asociadas a estos derivadores se dirigieron hacia el sur cuando, por la fase de la marea (vaciante), cabía esperar que su dirección sería hacia la boca del golfo. Estos resultados son consonantes con las observaciones de Alcántara et al. (2019), que mencionan una relación entre la espiga litoral de punta
Gulf of Urabá, sea-land breezes can be expected to be directed towards the head of the Gulf during the day and towards the mouth of the Gulf during the night (Arroyo, 2019). The result is a 24-h weather cycle in the inner part of the Gulf, with the sea level increasing in the afternoon and decreasing in the early morning. This cycle would be approximately in phase with the astronomical tide during round 3 and out of phase during the other rounds. These results are consistent with those recorded by Toro et al. (2019) for certain times of the year in the Gulf of Urabá, where wind directions and currents are in phase, specifically during October and December with southerly winds and stronger currents.

Regarding other factors, the observations presented here show that both tidal wave variation and wind intensity have an important effect on coastal currents in the region, but also point to the need to consider other factors in the modification of the current pattern and the tidal wave lag. Among these factors are the adjacent coastal lagoons, such as El Uno and Turbo bays. Both geoforms are associated with the coastal spits derived from the mouth of the Turbo River, producing semi-enclosed bodies of water that can intensify the effect of the tide, mainly in terms of the velocity at times of draining and filling.

The results suggest a lag in the way drifter L1 (round 1), which was launched near Las Vacas spit in minimal wind and swell conditions, was pulled towards the interior of Turbo bay (Figure 4). Other examples are the routes taken by drifters L3 and L4 (round 2) and L3 (round 4), launched just in front of El Uno bay at times when the tide was ebbing; the currents that moved these drifters were headed south when they were expected to move towards the mouth of the Gulf because of the phase of the tide (ebb). These results are consistent with the observations of Alcántara et al. (2019), who mention a relationship between the coastal outcrop at Yarumal spit in El Uno bay, the outflow of the Turbo River and the tidal currents at the bay's inlets that prevent them from closing.

The pattern of currents during the dry season also points to the existence of a N-S drift current between Yarumal spit and Las Vacas spit. This current may be associated with the breaking waves caused by the increase in the northerly winds during those rounds conducted in the dry season (Table 1). This is consistent with the results of Escobar (2011), who suggests that the oblique wave breaking in shallow waters would cause the drift currents. Another possible modulator of currents in the Gulf of 
Yarumal en bahía El Uno, la descarga del río Turbo y las corrientes de marea en sus bocanas (inlets) que evitan que estas se cierren.

El patrón de corrientes durante la época de poca lluvia también sugiere la existencia de una corriente de deriva con dirección N-S entre punta Yarumal y Punta de Las Vacas. Esta corriente estaría asociada al rompimiento del oleaje ocasionado por el aumento de los vientos persistentes del norte durante las campañas realizadas en la época de poca lluvia (Tabla 1). Esto coincide con los resultados de Escobar (2011), quien sugiere que la rompiente del oleaje oblicuo en las aguas someras podría originar corrientes de deriva. Otro posible modulador de las corrientes en el golfo de Urabá es la descarga del río Atrato, al menos en la zona cercana al delta. Toro et al. (2019) encontraron las corrientes más intensas alrededor de las bocas del río en general durante todo el año, pero principalmente durante la época de mucha lluvia.

\section{CONCLUSIONES}

Las observaciones realizadas con los derivadores superficiales, junto con las series temporales de vientos y mareas, confirman que el ascenso y descenso de la marea viene asociado a un desplazamiento de las masas de agua hacia el sur y el norte del golfo. Al tratarse de un cuerpo semicerrado con orientación sur-norte, las corrientes de marea se dirigen hacia/desde la cabeza del golfo durante la marea llenante/vaciante, con una dirección aproximadamente perpendicular a la propagación de la fase de marea. En la zona de estudio, la onda de marea hace que las corrientes sean marcadamente paralelas a la costa.

Los resultados sugieren que durante la época de poca lluvia hay una notable influencia del viento del noroeste sobre las corrientes, posiblemente trazando una circulación anticiclónica (en el sentido horario) en la parte interior del golfo (desde la desembocadura del río Atrato hacia el sur). Como consecuencia, durante la época de poca lluvia, la dirección promedio del viento (noroccidente) coincidió con la dirección predominante de las corrientes hacia el sur. Esto sería la causa de una corriente de deriva en sentido N-S desde punta Yarumal hasta punta de Las Vacas, la cual podría ser la responsable del aporte de sedimentos a playa Dulce.

Las trayectorias de los derivadores y sus corrientes asociadas también apuntan a la influencia de la bahía El Uno. El llenado y vaciado de esta bahía sin duda experimenta
Urabá is the outflow of the Atrato River, at least in the vicinity of its delta. Toro et al. (2019) found the strongest currents around the river mouths in general throughout the year, but mainly during the rainy season.

\section{CONCLUSIONS}

Observations of the surface drifters, together with the wind and tidal time series, confirm that the rise and fall of the tide is associated with a southward and northward displacement of the water masses in the Gulf. Being a semi-enclosed body with a south-north orientation, the tidal currents are directed to and from the head of the Gulf during the rising and ebbing tide respectively, in a direction approximately perpendicular to the propagation of the tidal phase. In the study area, the tidal wave causes the currents to be sharply parallel to the coast.

The results suggest that during the dry season there is a notable influence of the northwesterly wind on the currents, possibly following an anticyclonic circulation (clockwise) in the inner part of the Gulf (from the mouth of the Atrato River to the south). As a consequence, during the dry season, the average wind direction (northwesterly) coincided with the prevailing current direction to the south. This would be the source of a N-S drift current from Yarumal spit to Las Vacas spit, which could be responsible for the deposition of sediments at Playa Dulce.

The paths taken by the drifters and the currents that guided them also point to the influence of El Uno bay. The filling and draining of this bay are undoubtedly delayed with respect to the tide in the waters of the Gulf itself, and thus would be able to modify the current system in the surrounding area. This could be the reason why some drifters start to head towards the bay's inlet during the rising tide or why the water flows away from the inlet, for example towards the mouth of the Gulf, when the tide is outgoing.

Our results suggest that both the tide and wind modulate the coastal current system in the interior of the Gulf. However, in this study we have used the tidal elevation values recorded at Sapzurro, which is located in the northern end of the Gulf. Therefore, the results cannot be conclusive since the tidal wave lag between the northern part of the Gulf and the study area could not be accurately quantified. Calculations based on the speed of tidal propagation in shallow waters suggest a delay of about two hours. A suggestion for future studies of coastal 
un retraso con respecto a la marea en las aguas del propio golfo, de modo que sería capaz de modificar el sistema de corrientes en el área circundante. Esto podría ser la causa de que algunos derivadores se orienten hacia la entrada de esta bahía durante la marea llenante o que el agua diverja de esa entrada, dirigiéndose por ejemplo hacia la boca del golfo, durante periodos de vaciante.

Nuestros resultados sugieren que la marea y viento modulan conjuntamente al sistema de corrientes costeras en el interior del golfo. Sin embargo, para nuestro estudio hemos utilizado los valores de elevación de la marea en Sapzurro, que está localizado en la parte norte del golfo. Por tanto, los resultados no permiten ser concluyentes ya que no se ha podido cuantificar de forma exacta el desfase de la onda de marea entre la parte norte del golfo y el área de estudio. Cálculos basados en la velocidad de propagación de la marea en aguas someras, sugiere un retraso de unas dos horas. Se sugiere que en estudios futuros de las corrientes costeras se considere el oleaje y la descarga del río Atrato.

Aunque las mediciones se realizaron relativamente cerca de la costa, no son suficientes para determinar los riesgos a los que podrían estar expuestos los bañistas de playa Dulce, ni la influencia de la estructura de protección costera construida allí. Nuestros resultados confirman la necesidad de realizar mediciones simultáneas de variables como nivel del mar, corrientes, oleaje y viento de manera sistemática. Por último, este estudio subraya la posibilidad de realizar una aproximación a la dinámica del campo de corrientes en regiones costeras con instrumentos de bajo costo.

\section{AGRADECIMIENTOS}

Al semillero de Instrumentación Oceanográfica de la sede de Ciencias del Mar por el apoyo en el préstamo de los derivadores de bajo costo y demás instrumentos utilizados en las campañas. $\mathrm{Al} \mathrm{CIOH}$ por el suministro de los datos meteomarinos del golfo de Urabá. Parte de esta investigación se realizó en el marco del proyecto "Colaboración para la formulación de un Proyecto observatorio oceanográfico, atmosférico y ambiental de los golfos del Darién y Urabá, Colombia", referencia COOPB20337, financiado por la Agencia Estatal: Consejo Superior de Investigaciones Científicas, España (CSIC). currents is to also consider the swell and discharge of the Atrato river.

Although the measurements were taken relatively close to the coast, they were not sufficient to determine the risks to which bathers at Playa Dulce might be exposed, nor the influence of the coastal protection structure built there. Our results confirm the need for simultaneous measurements of variables such as sea level, currents, waves and wind in a systematic manner. Finally, this study demonstrates that it is possible to assess the dynamics of the current field in coastal regions with low-cost instruments.

\section{ACKNOWLEDGMENTS}

We would like to thank the Instrumentation Hotbed of the Marine Sciences Campus for the support provided through the loan of low-cost drifters and other instruments used in the study. We also thank the $\mathrm{CIOH}$ for providing meteomarine data for the Gulf of Urabá. Part of this research was carried out within the framework of the project "Collaboration for the development of an oceanographic, atmospheric and environmental observatory project for the Gulfs of Darién and Urabá, Colombia", reference COOPB20337, financed by the State Agency: Consejo Superior de Investigaciones Científicas, Spain (CSIC). 


\section{BIBLIOGRAFÍA / LITERATURE CITED}

Alcántara, J., A. Caicedo., J. Hernández., A. Jaramillo-Vélez and R. Manzolli. 2019. Sediment bypassing from the new human-induced lobe to the ancient lobe of the Turbo delta (Gulf of Urabá, Southern Caribbean Sea). J. Coast. Res., 35(1): 196-209.

Arroyo, L.M. 2019. Caracterización del ciclo de brisas diurnas en el Golfo de Urabá a partir de resultados del modelo atmosférico WRF. Universidad de Antioquia, Ingeniería Ambiental, Turbo, Colombia. $56 \mathrm{p}$.

Brakenridge, G. R. Kettner, A.J. Paris, S. Cohen, S. and S. Nghiem. 2021. River and reservoir watch Version 4.0. DFO Flood Observatory, University of Colorado, USA. http://floodobservatory.colorado.edu/SiteDisplays/40.htm. Fecha de consulta: 03/02/2021.

CIOH. 2017. Pronóstico del nivel del mar para el golfo de Urabá. Cartagena, Colombia. https://www.cioh.org.co/meteorologia/mareas.php. Fecha de consulta: $10 / 10 / 2017$.

Correa, I. D. y G. Vernette. 2004. Introducción al problema de la erosión litoral en Urabá (sector Arboletes-Turbo) Costa Caribe Colombiana. Bol. Invest. Mar. Cost., 33: 7-28.

Correa-Ramírez, M., A. Rodríguez-Santana., C. Ricaurte-Villota and J. Páramo. 2020. The Southern Caribbean upwelling system off Colombia: Water masses and mixing processes. Deep Sea Res. Part I: Oceanogr. Res. Pap., 155: 103145.

Escobar, A. 2011. Relevancia de procesos costeros en la hidrodinámica del golfo de Urabá (Caribe colombiano). Bol. Invest. Mar. Cost., 40(2): $327-346$.

Escobar, C., L. Velásquez and Posada, F. 2015. Marine Currents in the Gulf of Urabá, Colombian Caribbean Sea. J. of Coast. Res. 31(6), $1363-1374$.

Grifoll, M., A. Aretxabaleta, J.L. Pelegri and M. Espino. 2016. Temporal evolution of the momentum balance terms and frictional adjustment observed over the inner shelf during a storm. Oc. Sci., 137-151.

Godin, G. 1993. On tidal resonance. Cont. Shelf Res., 13: 89-107.

Higuita. M. y R. Quintana. 2020. Modulación de las corrientes oceánicas en el golfo de Urabá a partir de la onda de marea. Tesis de grado, Oceanografía e Ingeniería Oceanográfica. Universidad de Antioquia. Turbo. 55 p.

IDEAM. 2019. Pronóstico de pleamares y bajamares en la costa Caribe colombiana 2020. $171 \mathrm{p}$.

Invemar. 2003. Diagnóstico, zonificación y definición de la estructura administrativa y manejo de la unidad costera del Darién, Caribe colombiano. Fase I. Caracterización y diagnóstico. Informe técnico. 698 p.

Kjerfve, B. 1981. Tides of the Caribbean Sea. J. Geophys. Res., 96, 4243-4247.

Lonin, S. y J.G. Vásquez. 2005. Hidrodinámica y distribución de coliformes en el Golfo de Urabá. Bol. Cient. CIOH, 23: 76-89.

Lozano-Duque, Y., J. Medellín-Mora y G.R. Navas. 2010. Contexto climatológico y oceanográfico del mar Caribe colombiano: 54-84. En Biodiversidad del margen continental del Caribe colombiano, Invemar Serie Publ. Espec., 20.

Lucero, M. y M. Mindiola. 2007. Distribución de las corrientes superficiales y subsuperficiales en la Caleta Aeolian-isla Baltra, Ecuador. Acta Oceanogr. Pac., 14: 14-19.

MacMahan, J., J. Brown and E. Thornton.2009. Low-cost handheld Global Positioning System for measuring surf-zone currents. J. Coast. Res., 25(3): 744-754.

Montoya, L. y M. Toro. 2006. Calibración de un modelo hidrodinámico, para el estudio de los patrones de circulación del golfo de Urabá, Colombia. Av. Rec. Hidr., 13: 37-54.

Nienhuis, J. 2019. Local wave and tide data. Earth Engine App. https://jhnienhuis.users.earthengine.app/view/changing-shores. Fecha de consulta: 19/11/2019.

Proudman, J. 1953. Dynamical oceanography. Methuen, London, 409 p.

Prüssmann-Uribe, J. e I.D. Correa-Arango. 2012. Base de datos espacial geomorfológica de la franja litoral de los departamentos de Antioquia y Chocó. Geol. Col., 37(1): 47-48.

Ricaurte-Villota, C. y M.L. Bastidas Salamanca. 2017. Regionalización oceanográfica: una visión dinámica del Caribe.Ser. Publ. Espec., Invemar 14, 180 p.

Shafiei, B. and G. Abbas. 2011. Design of small GPS drifters for current measurements in the coastal zone. Oc. Coast. Manag., 54(2): 158-163.

Toro, V., W. Mosquera, N. Barrientos e Y. Bedoya. 2019. Circulación oceánica del golfo de Urabá usando campos de vientos de alta resolución temporal. Bol. Cient. CIOH. 38 (2): 26-35.

Wu, J. 1983. Sea-surface drift currents induced by winds and waves. J.Phys. Oceanogr., 13: 1441-1451.

RECIBIDO/RECEIVED: 13/04/2020

ACEPTADO/ACCEPTED: 16/04/2021 